\title{
$\beta$-Lactoglobulin Adsorption Layers at the Water/Air Surface: 4. Impact on the Stability of Foam Films and Foams
}

\author{
Georgi G. Gochev ${ }^{1,2, * \mathbb{C}}$, Vamseekrishna Ulaganathan ${ }^{3}$, Inga Retzlaff ${ }^{4}$, Cécile Gehin-Delval ${ }^{5}$, \\ Deniz Z. Gunes ${ }^{5}$, Martin Leser ${ }^{5}$, Ulrich Kulozik ${ }^{6} \mathbb{(}$, Reinhard Miller ${ }^{4,7} \mathbb{D}$ and \\ Björn Braunschweig ${ }^{8}$ D \\ Jerzy Haber Institute of Catalysis and Surface Chemistry, Polish Academy of Sciences, 30239 Krakow, Poland \\ Institute of Physical Chemistry, Bulgarian Academy of Sciences, 1113 Sofia, Bulgaria \\ Institute of Biomaterial Science, Helmholtz-Zentrum Geesthacht, 14513 Teltow-Seehof, Germany; \\ vamseekrishna.ulaganathan@hzg.de \\ 4 Max Planck Institute of Colloids and Interfaces, 14476 Potsdam, Germany; inga.retzlaff@gmail.com (I.R.); \\ miller@fkp.tu-darmstadt.de (R.M.) \\ 5 Nestlé Research Center, CH-1000 Lausanne 26, Switzerland; Cecile.Gehin-Delval@rdor.nestle.com (C.G.-D.); \\ ZeynelDeniz.Gunes@rdls.nestle.com (D.Z.G.); Martin.Leser@rdls.nestle.com (M.L.) \\ 6 Chair of Food and Bioprocess Engineering, TU Munich, 85354 Freising, Germany; ulrich.kulozik@tum.de \\ 7 Department of Physics, TU Darmstadt, 64289 Darmstadt, Germany \\ 8 Institute of Physical Chemistry and Center for Soft Nanoscience, WWU Münster, 48149 Münster, Germany; \\ braunschweig@uni-muenster.de \\ * Correspondence: ncgochev@cyf-kr.edu.pl or gochev@ipc.bas.bg
}

Received: 5 June 2020; Accepted: 14 July 2020; Published: 17 July 2020

Abstract: The complexity and high sensitivity of proteins to environmental factors give rise to a multitude of variables, which affect the stabilization mechanisms in protein foams. Interfacial and foaming properties of proteins have been widely studied, but the reported unique effect of $\mathrm{pH}$, which can be of great interest to applications, has been investigated to a lesser extent. In this paper, we focus on the impact of $\mathrm{pH}$ on the stability of black foam films and corresponding foams obtained from solutions of a model globular protein - the whey $\beta$-lactoglobulin (BLG). Foam stability was analyzed utilizing three characteristic parameters (deviation time, transition time and half-lifetime) for monitoring the foam decay, while foam film stability was measured in terms of the critical disjoining pressure of film rupture. We attempt to explain correlations between the macroscopic properties of a foam system and those of its major building blocks (foam films and interfaces), and thus, to identify structure-property relationships in foam. Good correlations were found between the stabilities of black foam films and foams, while relations to the properties of adsorption layers appeared to be intricate. That is because $\mathrm{pH}$-dependent interfacial properties of proteins usually exhibit an extremum around the isoelectric point (pI), but the stability of BLG foam films increases with increasing $\mathrm{pH}$ (3-7), which is well reflected in the foam stability. We discuss the possible reasons behind these intriguingly different behaviors on the basis of $\mathrm{pH}$-induced changes in the molecular properties of BLG, which seem to be determining the mechanism of film rupture at the critical disjoining pressure.

Keywords: $\beta$-lactoglobulin; $\mathrm{pH}$ effect; foam; foam film; adsorption layer; drainage; coalescence; disjoining pressure

\section{Introduction}

Foams are dispersed systems of gas in a liquid matrix. Foams are found in nature and are also widely used in various technologies; therefore, they are of continuous interest to science since 
the works of Plateau in the 19th century [1,2]. Nevertheless, a general theory to describe foam behavior is still lacking. This is because the formation of foam and its further existence involves a multitude of phenomena at different length scales, among which interfacial phenomena play crucial roles [1-14]. The creation of foam is a highly hydrodynamic process [15] and requires the presence of surface-active agents, which can adsorb at the foam interfaces reducing their free energy, and thus, reducing the global free energy of such an interface-dominated system. Once the foam is being created, its evolution towards decaying properties is determined by different destabilizing mechanisms (syneresis, coarsening, coalescence [4-7]), but the foam can reach a quasi-static state under hydrostatic equilibrium (dry foam).

Studies on foam stability are rather subjective, due to lack of a universal standard for generating foam-stabilities of foams made of a given solution can be specific to the conditions under which the foams are produced, and one should always keep this in mind when comparing results for similar systems [10]. Several characteristic parameters (bubble size and volume fraction distributions, the height of a generated foam column, characteristic time parameters of foam decay, etc.) have been used to describe foamability and foam stability $[2-6,16,17]$. One of the most popular parameters for describing the decay of a foam column is the foam half-lifetime $t_{1 / 2}$, i.e., the time when the foam reaches half of its initial height. However, this parameter cannot recognize the individual impacts from different destabilization mechanisms. In this respect, Lunkenheimer et al. [16] introduced two characteristic parameters: time of deviation $t_{d e v}$ and the time of transition $t_{t r}$, which indicate the onset and the maximum rate of bubble coalescence in the course of foam decay, respectively; thus, allowing for discrimination (at least to some extent) between the interrelated actions of syneresis and coalescence. Moreover, it was found for surfactant stabilized foams that there is a linear relation between $t_{1 / 2}$ and $t_{\text {tr }}$, but it was also suggested that $t_{\text {tr }}$ allows a better description of the foam behavior [16].

Even if the evolution of the macroscopic properties of a given foam can be well described, revealing the reasons for the observed behavior, and thus, designing strategies for foam control require further knowledge on the microscopic level. In this respect, multi-scale approaches have been used, where macroscopic foaming properties are compared with the microscopic (nanoscopic) properties of lamellae (foam films) and interfaces [18-27] as foam's building blocks. Regarding interfaces, on the focus are the traditional adsorption dynamics studies, as well as rheological [9-14,17-46], electrical $[27,29,35,47-51]$, and structural $[30,50,51]$ interfacial characteristics-it is emphasized the crucial role of the rate of adsorption, surface viscoelasticity (surface elasticity is the resistance force to mechanical disturbances), interface charging state and interfacial molecular organization, respectively, to foamability, foam stability and foam rheology. Pronounced viscoelastic characteristics of interfaces have been recognized to enhance foaming properties $[10,11,14,28,31]$. Natural and technical foams are usually polydisperse, which results in a spectrum of capillary pressures in the Plateau borders and the nodes that are counterbalanced by the action of the disjoining pressure in the foam films. Direct correlations between the foam and the corresponding foam films can be, however, difficult. While experiments with single foam films are usually performed under well-defined conditions, the interconnected lamellae in a macroscopic foam can experience the simultaneous action of several processes, e.g., lamella bursting can cause so-called 'collective effects' inducing pressure shocks, interfacial shear and dilational perturbations, surface tension (excess) gradients, local enrichment of surface-active material, etc. $[4,10,18,52-54]$.

Proteins are broadly used as stabilizers of dairy foams. The complexity and high sensitivity of globular proteins to environmental conditions make it difficult to describe their impact on the mechanisms of foam (de)stabilization $[8,9,11,12,14,26]$. Moreover, protein aggregation (reversible or irreversible) can have complex (enhancing/inhibiting) influence on interfacial and foaming properties as compared to those of the respective native protein $[8,19,39-44,49,55]$. The behavior of proteins at interfaces and in corresponding foam films and foams is governed by the interplay of the protein concentration and the solvent conditions (salt type and concentration, $\mathrm{pH}$ ), and the unique effect of $\mathrm{pH}$ is of special interest. 
The whey globular protein $\beta$-lactoglobulin (BLG) is frequently used as a model protein in foam and interfacial studies. Adsorption dynamics and surface rheology of native BLG layers at static water/air interfaces [8,25,35-38,56-60], as well as foam film thickness [25,61], have been previously studied as affected by $\mathrm{pH}$. It was proven by vibrational sum-frequency generation (SFG) spectroscopy that the $\mathrm{pH}$-dependent net charge of BLG in solution determines the magnitude of the electric field at the solution's interface and thereof, a charge reversal can occur when the isoelectric point of BLG moieties $(\mathrm{pI} \approx 5.1$ ) is crossed [35]. Under the latter conditions maxima in the $\mathrm{pH}$-dependencies of the surface pressure and surface excess $[35,58,60]$, as well as of the surface shear elastic and viscous moduli [56] are observed, while at the same time foam film thickness drops to a minimum, and foam Newton black films (NBF) are obtained [61]. A qualitative inference of the adsorption process at the interface of a rising bubble in BLG solution was also earlier obtained; the results, however, showed that the $\mathrm{pH}$-dependent bubble motion contravened the above-discussed trends and the bubble rising velocity increase with increasing $\mathrm{pH}$ in the studied range 3-7 [62].

Nevertheless, these trends are not necessarily valid for the $\mathrm{pH}$-dependent behavior of protein foams. For example, different stabilities have been observed for foams obtained from protein solutions that have similar surface pressures and dilational viscoelasticity moduli and were found to produce foam films with comparable thicknesses [22,25,61]. For BLG, Lech et al. [25] reported poor foamability and foam stability at $\mathrm{pH} 3$, while those were much better for $\mathrm{pH} 7$; at the same time, at $\mathrm{pH} 5$ foam half-lifetime increased in a jump-like manner with the increase of the BLG concentration-again, foam stability could not be explained by the interfacial characteristics and the film thickness investigated in the same study. Previous studies showed that the stability against the rupture of single foam films could be well correlated with foam stability $[18,27,52,53]$, Therefore, in the present study, we aim at elucidating the reasons of the peculiar $\mathrm{pH}$-dependent behavior of BLG foams by investigating the stability of BLG foam films. We present experimental results on foam films and foams obtained from solutions with two different BLG concentrations, but at a constant buffer concentration of $10 \mathrm{mM}$ (which induces the formation of black foam films [61]). Foam stability is described by the characteristic times $t_{1 / 2}, t_{\text {dev }}$ and $t_{t r}$. Single black foam films were investigated in a porous plate cell to determine their stability in terms of the critical disjoining pressure of film rupture, $\Pi_{c r},[18,52,53]$. In this fourth part of the series, we discuss the obtained results in the context of our three previous papers [58-60] from this series, as well as of the above-mentioned literature results.

\section{Materials and Methods}

\subsection{Chemicals and Solutions}

Native $\beta$-lactoglobulin (molecular weight $\approx 18.3 \mathrm{kDa}$ ) has been isolated and purified from whey protein isolate (WPI) as starting material (Davisco, Le Seur, Minnesota, USA, protein content of $94 \%$ based on dry matter, comprising 18\% $\alpha$-lactalbumin, $44 \% \beta$-lg genetic variant $\mathrm{A}, 30 \% \beta$-lactoglobulin genetic variant $B$, and $8 \%$ minor proteins) by a very mild selective thermal aggregation $\left(50 \pm 1{ }^{\circ} \mathrm{C} /\right.$ held for $120 \mathrm{~min}$ ) under milieu conditions (addition of citric acid and trisodium citrate to adjust $\mathrm{pH}$ 3.4 and to capture the calcium ion stabilizing $\alpha$-Lactalbumin). Under these conditions, the other whey proteins (mainly $\alpha$-lactalbumin, BSA and immunoglobulins) were destabilized, while BLG was not affected. By subsequent microfiltration/ultrafiltration in diafiltration mode and spray drying, a powder of native BLG at high yield $(>95 \%)$ was obtained. The procedure was described in detail in [63]. Analysis of native whey proteins was carried out by reversed-phase RP-HPLC, also described in detail in [63]. The powder sample used in the present study contained total protein $\approx 98.9 \%$ (of which BLG content $>99 \%$, ratio of BLG-A/BLG-B $\approx 1.22$ ), salts $\approx 0.7 \%$, and traces of lactose $(<0.05 \%$ ). Aqueous solutions were prepared in $\mathrm{Na}_{2} \mathrm{HPO}_{4} / \mathrm{Citric}$ acid/Milli-Q buffers by keeping a constant buffer concentration of $C_{\text {buff }}=10 \mathrm{mM}$ and varying the BLG concentration $\left(C_{B L G}\right)$ and $\mathrm{pH}$. All experiments were performed at room temperature of $\approx 22^{\circ} \mathrm{C}$. 


\subsection{Foams}

A dynamic foam analyzer DFA100 (Krüss, Hamburg, Germany) was used for foam stability measurements. It consists of a glass column, which is equipped with a light sensor array and a LED light panel. The whole glass column is scanned in real-time, and the intensity of the light detected by the sensors records the height of the foam $\mathrm{H}_{\mathrm{F}}$ and the height of the solution $\mathrm{H}_{\mathrm{L}}$ at the bottom of the glass column [2]. In a typical experiment, the instrument was programmed to sparge air through the porous frit (pore size 10-16 $\mu \mathrm{m}$ ) at a flow rate of $0.15 \mathrm{~L} / \mathrm{min}$ until the foam reached a height of $\mathrm{H}_{\mathrm{F}}=160 \mathrm{~mm}$. Subsequently, the gas flow was stopped automatically. Then, $50 \mathrm{~mL}$ of BLG solution was gently poured into the glass cylinder, which resulted in a bubble-free liquid height of about $40 \mathrm{~mm}$, and therefore, the total height of the foam and the liquid was about $200 \mathrm{~mm} . \mathrm{H}_{\mathrm{F}}$ and $\mathrm{H}_{\mathrm{L}}$ were automatically scanned by the device at regular intervals of $1 \mathrm{~s}$ (Figure 1a) and with heights' resolution better than $0.5 \mathrm{~mm}$ (see Figure S2 in the Supplementary Materials). The time when the foam height reached a maximum value $\mathrm{H}_{\mathrm{F}}{ }^{\max }$ (while the liquid height reached a minimum value $\mathrm{H}_{\mathrm{L}}{ }^{\mathrm{min}}$ ) was set as the time origin $t_{0}=0$ from which the foam decay was further monitored. Thus, the following absolute changes in the foam's and liquid's heights were calculated as:

$$
\begin{aligned}
& \Delta \mathrm{H}_{\mathrm{F}}\left(\mathrm{t}_{i}\right)=\mathrm{H}_{\mathrm{F}}^{\max }\left(\mathrm{t}_{0}\right)-\mathrm{H}_{\mathrm{F}}\left(\mathrm{t}_{i}\right), \\
& \Delta \mathrm{H}_{\mathrm{L}}\left(\mathrm{t}_{i}\right)=\mathrm{H}_{\mathrm{L}}\left(\mathrm{t}_{i}\right)-\mathrm{H}_{\mathrm{L}}{ }^{\min }\left(\mathrm{t}_{0}\right) .
\end{aligned}
$$

In this way, $\Delta \mathrm{H}_{\mathrm{F}}(\mathrm{t})$ and $\Delta \mathrm{H}_{\mathrm{L}}(\mathrm{t})$ data (Figure $1 \mathrm{~b}$ ) were collected for each of the studied foams.

Foam stability was analyzed in terms of the foam half-lifetime $t_{1 / 2}$, as well as of the characteristic times $t_{d e v}$ and $t_{\operatorname{tr}}[2,6,16]$. The latter two parameters define certain stages of the foam decay where different destabilization mechanisms (syneresis and coalescence) predominantly operate. According to this approach, the foam decay can be characterized by three main stages separated by the characteristic time parameters $t_{d e v}$ (onset of coalescence) and $t_{t r}$ (maximum rate of coalescence).

The first stage lasts from $t_{0}$ up to the time of deviation $t_{d e v}$, defined by Equation (3). In this initial period of the foam decay, rapid efflux of liquid from the fresh wet foam takes place; the bubbles get closer, which leads to the formation of foam films, Plateau borders and nodes. The syneresis dynamics is dominated by the gravity-driven drainage in Plateau borders and nodes, but at the same time, films start to drain as well, due to the capillary pressure in the Plateau borders. Indeed, the amount of liquid drained from such freshly formed (thick) films should be a small fraction of all the draining liquid. However, what is most important in this stage of foam decay is that the films presumably do not coalesce yet. Hence, the decrease in foam height is at this point equal to the increase of the height of the solution beneath the foam (see Figure 1b), that is:

$$
\Delta \mathrm{H}_{\mathrm{F}}\left(\mathrm{t} \leq \mathrm{t}_{\mathrm{dev}}\right)=\Delta \mathrm{H}_{\mathrm{L}}\left(\mathrm{t} \leq \mathrm{t}_{\mathrm{dev}}\right)
$$

After $t_{d e v}$, the foam system enters an intermediate period of its decay, where the films can be still draining or have reached their equilibrium thickness. However, in both cases, film rupture can take place that means coalescence of bubbles starts to operate along with the foam syneresis. The liquid volume fraction in the foam progressively decreases with time, that is the syneresis diminishes, and the process of coalescence becomes predominant. Under such conditions, the foam enters the final stage of its decay at the characteristic time $t_{t r}$, where the rate of bubbles coalescence is at maximum, and the syneresis is negligible, i.e., the state of quasi-static dry foam is reached. 

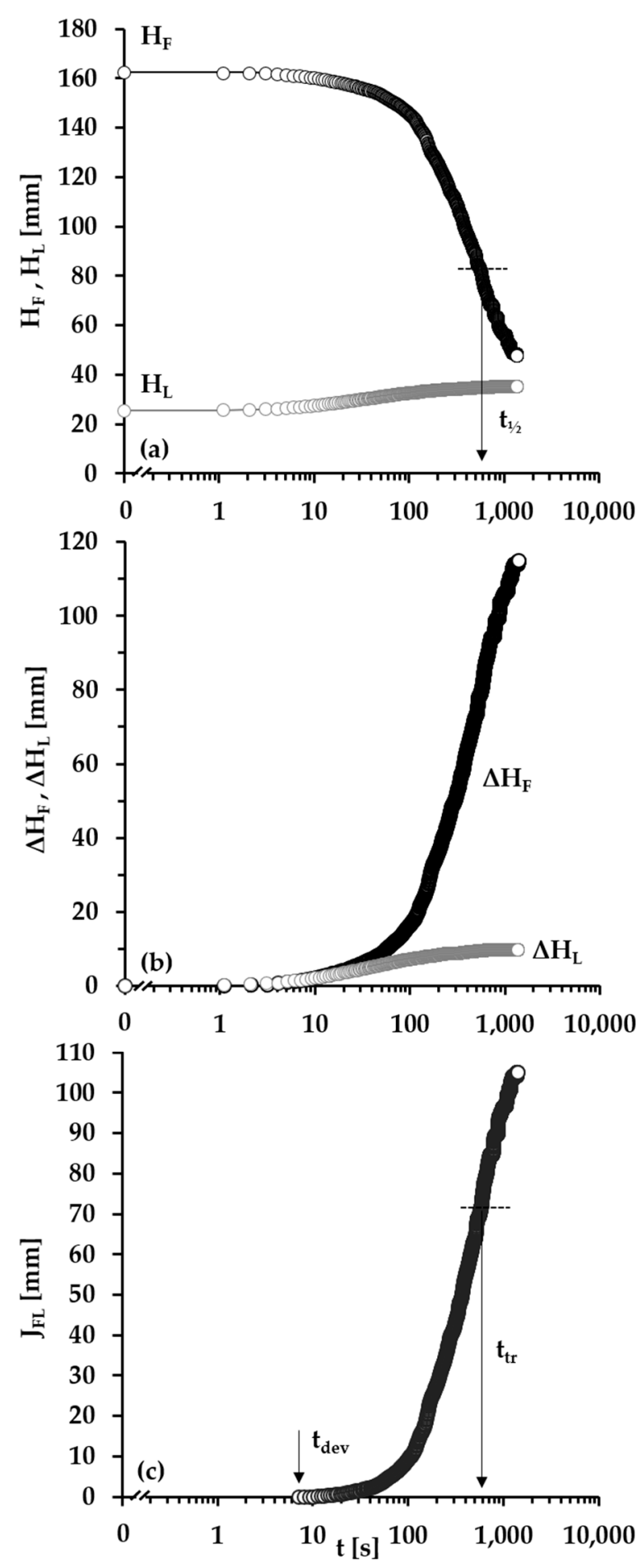

Figure 1. Foam obtained from a $100 \mu \mathrm{M} \beta$-lactoglobulin (BLG) solution at $\mathrm{pH} 3$ and $\mathrm{C}_{\text {buff }}=10 \mathrm{mM}$. (a) $\mathrm{H}_{\mathrm{F}}(\mathrm{t})$ and $\mathrm{H}_{\mathrm{L}}(\mathrm{t})$ kinetic curves; (b) $\Delta \mathrm{H}_{\mathrm{F}}(\mathrm{t})$ and $\Delta \mathrm{H}_{\mathrm{L}}(\mathrm{t})$, and (c) $\mathrm{J}_{\mathrm{FL}}(\mathrm{t})$ dependencies. For definitions of these quantities and of the characteristic parameters $t_{d e v}$ and $t_{t r}$ see Equations (1)-(5). Lines are guides to the eye; arrows indicate characteristic times.

The evaluation of the parameter $t_{\operatorname{dev}}$ can be done in several ways, satisfying Equation (3). It is directly obtained from a common plot of the kinetic dependences $\Delta \mathrm{H}_{\mathrm{F}}(\mathrm{t})$ and $\Delta \mathrm{H}_{\mathrm{L}}(\mathrm{t})$, as shown in 
Figure $1 b$, the two curves split at $t_{\mathrm{dev}}$. Values for $t_{\mathrm{dev}}$ can also be obtained from the initial linear portion of the $\Delta \mathrm{H}_{\mathrm{F}}(\mathrm{t})$ vs. $\Delta \mathrm{H}_{\mathrm{L}}(\mathrm{t})$ dependence (Figure $\mathrm{S} 2$ in the Supplementary Materials). Also, the quantity

$$
\mathrm{J}_{\mathrm{FL}}(\mathrm{t})=\Delta \mathrm{H}_{\mathrm{F}}(\mathrm{t})-\Delta \mathrm{H}_{\mathrm{L}}(\mathrm{t})
$$

can be conveniently plotted as a function of time, which indicates the position of $t_{\mathrm{dev}}$ at the onset of $\mathrm{J}_{\mathrm{FL}}(\mathrm{t})>0$ (Figure 1c). The latter dependence is further used to evaluate the other characteristic parameter, time of transition $t_{\mathrm{tr}}$. This characteristic time is defined as coinciding with the inflection point of such function with the limits $[2,16]$ :

$$
\mathrm{J}_{\mathrm{FL}}\left(\mathrm{t} \leq \mathrm{t}_{\mathrm{dev}}\right)=0 \text { and } \mathrm{J}_{\mathrm{FL}}(\mathrm{t} \rightarrow \infty) \rightarrow \text { const }
$$

To evaluate $t_{t r}$ we fitted each experimental $J(t)$ curve for $t>t_{d e v}$ with a cubic spline function and obtained the inflection point at the zero value or null point of its second derivative.

The characteristic times $t_{\mathrm{dev}}$ and $t_{\mathrm{tr}}$ give valuable information about the evolution of the foam decay in terms of recognizing the interplay between syneresis and coalescence, and getting insights into the timescale and the magnitude of their individual and simultaneous actions.

\subsection{Foam Films}

Thin foam films were studied in a porous plate cell $[27,64-66]$ with a radius of the hole in the frit film holder of $\mathrm{R}=1 \mathrm{~mm}$, enclosed in a sealed chamber (Figure 2). Further details on the cell and the setup have been reported elsewhere [66]. In such configuration, a foam film is formed in the center of a solution drop entrapped in the hole of the frit that is soaked with the solution under investigation. The disjoining pressure $\Pi$ of an equilibrium film equals the balance of the acting pressures in the system and the geometry of the measuring cell $[65,66]$ :

$$
\Pi=\mathrm{P}_{\mathrm{a}}-\mathrm{P}_{\mathrm{r}}+\mathrm{P}_{\mathrm{c}}-\mathrm{P}_{\mathrm{h}}=\Delta \mathrm{P}+2 \gamma / \mathrm{r}_{\mathrm{c}}-\Delta \rho g \mathrm{z}_{\mathrm{c}}
$$

where $\Delta \mathrm{P}$ is the difference between the pressure applied in the chamber $\mathrm{P}_{\mathrm{a}}$ and the reference ambient pressure $\mathrm{P}_{\mathrm{r}}$ (usually the atmospheric pressure); $\mathrm{P}_{\mathrm{C}}$ and $\mathrm{P}_{\mathrm{h}}$ are capillary and hydrostatic pressures, respectively; $\gamma$ is the surface tension of the solution, from which the film is obtained; $r_{c}$ is the inner radius of the capillary; $\Delta \rho$ is the density difference between the solution and air; $g=9.81 \mathrm{~m} / \mathrm{s}^{2} ;$ and $\mathrm{z}_{\mathrm{C}}$ is the height of solution in the capillary above the film.

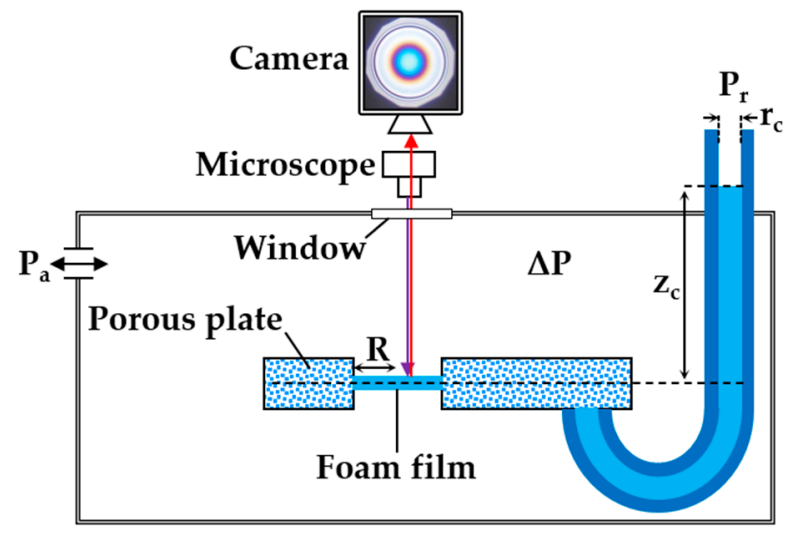

Figure 2. Schematic drawing of the porous plate cell set up for investigations of foam films.

Film stability was determined in terms of the critical disjoining pressure of film rupture $\Pi_{\mathrm{cr}}$ for films in saturated vapor conditions, and with a constant radius equal to that of the film holder $(1 \mathrm{~mm})$, i.e., the film occupies the whole area of the hole in the film holder. The experimental pressure limit of 
the porous frit (which the film holder is made of), i.e., the highest disjoining pressure that could be measured, was about $13 \mathrm{kPa}$; hence, the measured critical pressures were limited to this value. Due to the fluctuation nature of proposed mechanisms of film rupture $[64,65]$, the reported values for $\Pi_{\mathrm{cr}}$ are averaged from at least five independent measurements, and the standard deviation is given by the error bars in Figure 7. Note that for the most stable films at $\mathrm{C}_{\mathrm{BLG}}=100 \mu \mathrm{M}$ and at pH 6 and pH 7, some of the films did not rupture up to the experimental pressure limit.

\section{Results}

\subsection{Foam Films}

The pH-dependent electrostatics of BLG covered interfaces [35] play a key role in the properties of the corresponding foam films, such as the foam film thickness [25,61], and the disjoining pressure that keeps the two interfaces of a foam film apart [61]. In the present work, we investigated foam films for two protein concentrations of $\mathrm{C}_{\mathrm{BLG}}=10 \mu \mathrm{M}$ and $100 \mu \mathrm{M}$ but at constant buffer concentration of $\mathrm{C}_{\text {buff }}=10 \mathrm{mM}$, while the solution $\mathrm{pH}$ was adjusted at values of 3, 4, 5,6 and 7. At $10 \mathrm{mM}$ buffer and in the studied $\mathrm{pH}$ range, black films were obtained (Figures 4-6) for all systems studied. These films can be either 'common black films' (CBF) or 'Newton black films' (NBF) [61]. Foam films of the NBF type are readily obtainable at $\mathrm{pH} 5$ (which is close to the isoelectric point $\mathrm{pI}$ ) and at low disjoining pressures, while at $\mathrm{pH}$ values away from $\mathrm{pI}, \mathrm{CBF}$ are obtained. These CBF can, however, turn into NBF when the disjoining pressure $\Pi$ increases, a fact that has been previously revealed by disjoining pressure isotherm measurements [61].

The experiments were performed as follows. In the experimental protocol ' $\mathrm{A}$ ', a foam film was initially formed slowly by a gradual increase of the applied pressure $\mathrm{P}_{\mathrm{a}}$ in the sealed chamber. Once the film appeared in the center of the solution drop, $\mathrm{P}_{\mathrm{a}}$ was adjusted to yield a disjoining pressure of $\Pi=100 \mathrm{~Pa}$. For the different solutions in our study, we obtained film radii in the range of $0.2-0.3 \mathrm{~mm}$ (Figures 3-5). Once the pressure was adjusted, the foam films were left to thin and ideally reach a homogeneous pattern, which would be consistent with films having the same thickness independent of the lateral position within the film. However, this was not always possible due to film dimpling [67], and very slow drainage, typical for protein foam films $[19,20,61,67-71]$, especially at such a low disjoining pressure. Therefore, in many cases, inhomogeneous thick parts remained immobile within the films (Figures 3-6). After that, $\mathrm{P}_{\mathrm{a}}$ was increased in small steps of $100 \mathrm{~Pa}$ at a rate of $100 \mathrm{~Pa} / \mathrm{min}$ until the film occupied the complete available area. Under the experimental conditions, this was usually the case at about $\Pi=1 \mathrm{kPa}$. Note that at $\mathrm{pH} 3$ the foam films for both studied BLG concentrations of $10 \mu \mathrm{M}$ and $100 \mu \mathrm{M}$ were the least stable and ruptured already during this stage, without filling the available area in the film holder (Figure 4). For the other more stable systems, $\mathrm{P}_{\mathrm{a}}$ was gradually increased in a continuous mode at a rate of $1 \mathrm{kPa} / \mathrm{min}$ until the films ruptured. The disjoining pressure at film rupture is defined as $\Pi_{\mathrm{cr}}$. Several experiments were performed by a second protocol 'B', where the initial $\mathrm{P}_{\mathrm{a}}$ was set higher, and the films were rapidly formed at $\Pi \geq 1 \mathrm{kPa}$ (Figure 6). After that, $\mathrm{P}_{\mathrm{a}}$ was gradually increased as in protocol ' $A$ '. In a few experiments, films were left to relax at a given $\Pi$ in order to observe the film drainage (see in Figures 3 and 6, and Figure S6 in the Supplementary Materials).

Figure 7 shows the variation of the critical pressure of rupture $\Pi_{\mathrm{cr}}$ of BLG black foam films obtained from solutions with various $\mathrm{pH}$ and at the two BLG concentrations studied. The reported values for $\Pi_{\mathrm{cr}}$ are averaged from at least five independent measurements done mostly by protocol ' $\mathrm{A}$ ', but also including some results obtained by protocol ' $\mathrm{B}$ '. The standard deviation varied from $\pm 0.5 \mathrm{kPa}$ to $\pm 1.7 \mathrm{kPa}$, and we could not clearly distinguish certain effects of the different experimental protocols on the film stability. However, rapidly formed films exhibited much more irregular patterns (thickness inhomogeneities) and drained more slowly, which not always led to increased stability. Hence, we conclude that the way of film creation could have a relatively weak impact on the overall film stability. 


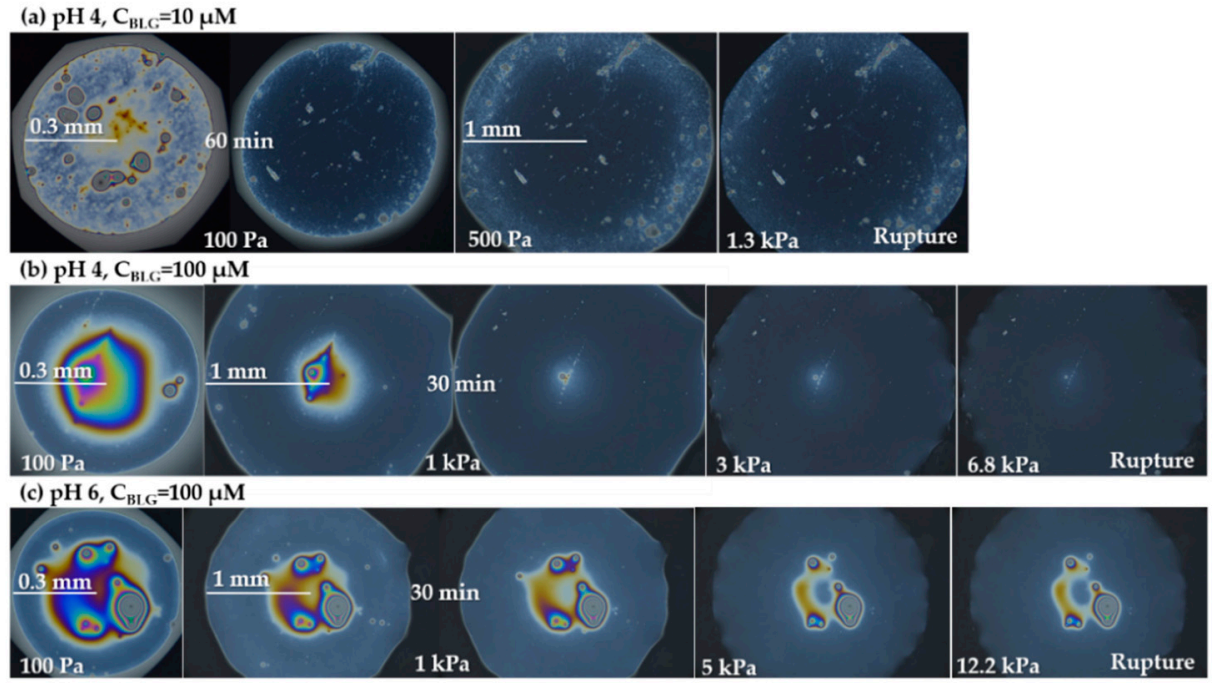

Figure 3. $(\mathbf{a}-\mathbf{c})$ Evolution of BLG black foam films at different $\mathrm{pH}$ and $\mathrm{C}_{\mathrm{BLG}}\left(\mathrm{C}_{\text {buff }}=10 \mathrm{mM}\right)$ formed slowly by protocol 'A'.

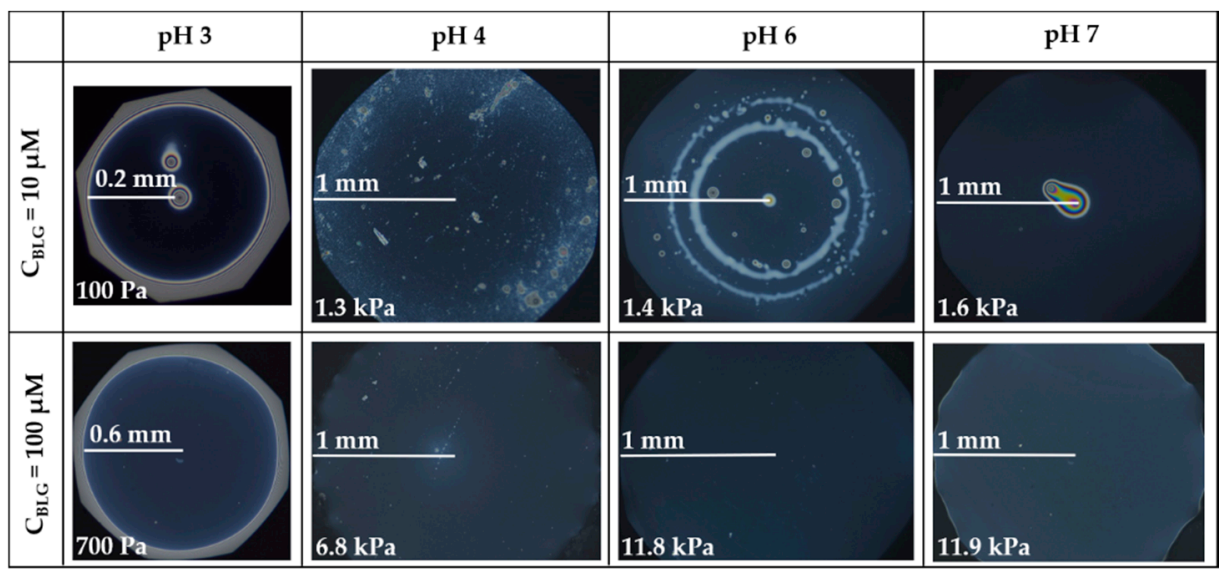

Figure 4. Black foam films obtained at different $\mathrm{pH}$ and $\mathrm{C}_{\mathrm{BLG}}\left(\mathrm{C}_{\mathrm{buff}}=10 \mathrm{mM}\right)$ formed slowly by protocol ' $\mathrm{A}$ '; the photos were taken at moments close to film rupture.

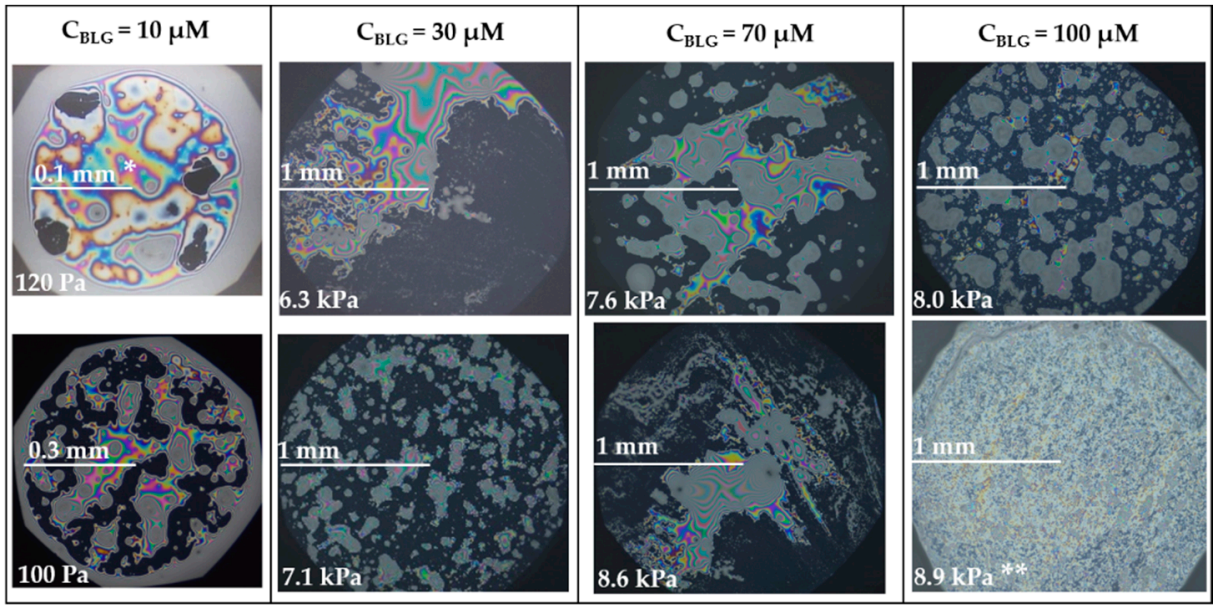

Figure 5. Foam Newton black films (NBFs) at different $\mathrm{C}_{\mathrm{BLG}}\left(\mathrm{pH} 5, \mathrm{C}_{\text {buff }}=10 \mathrm{mM}\right)$ formed slowly by protocol ' $\mathrm{A}$ '; the photos were taken at moments close to film rupture. * This film was obtained in a glass tube cell (see Figure S5 in the Supplementary Materials); ${ }^{* *}$ This film was formed rapidly by protocol 'B' (see Figure 6c). 

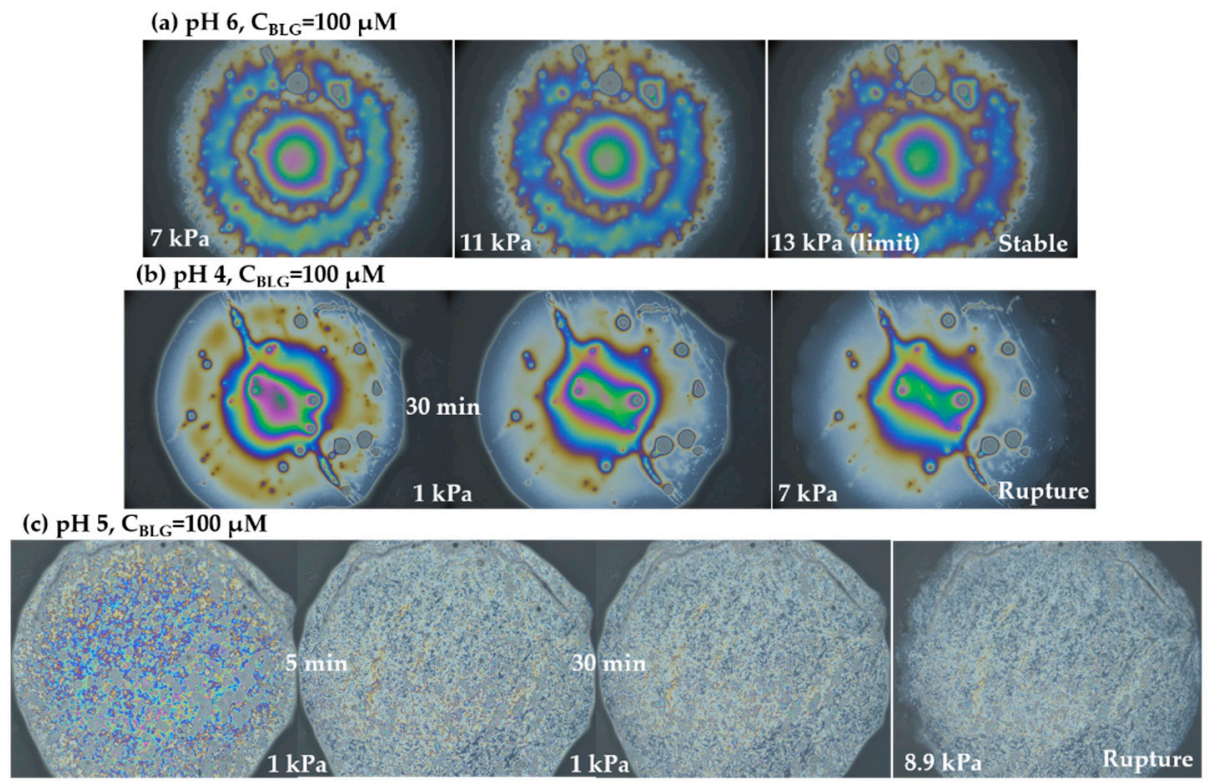

Figure 6. (a-c) BLG black foam films obtained at different $\mathrm{pH}$ and $\mathrm{C}_{\mathrm{BLG}}\left(\mathrm{C}_{\text {buff }}=10 \mathrm{mM}\right.$, radius of $1 \mathrm{~mm}$ ) formed rapidly by protocol ' $\mathrm{B}$ '.
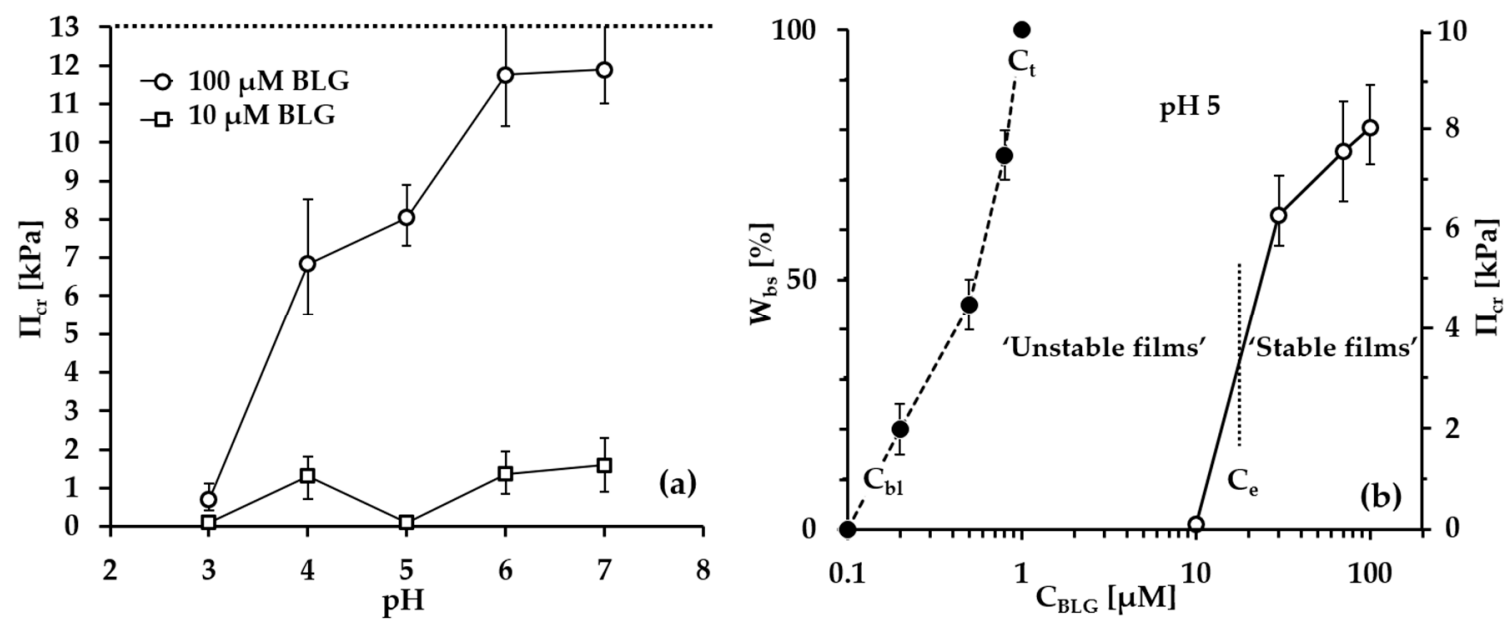

Figure 7. Black foam films obtained from solutions with different $\mathrm{pH}$ and $\mathrm{C}_{\mathrm{BLG}}\left(\mathrm{C}_{\text {buff }}=10 \mathrm{mM}\right)$. (a) Critical pressure of film rupture $\Pi_{\mathrm{cr}}$ as a function of $\mathrm{pH}$; dotted line indicates the experimental pressure limit. (b) Probability for observation of black spots in films $W_{\mathrm{bs}}(\bullet)$ and critical pressure of film rupture $\Pi_{\mathrm{cr}}(\bigcirc)$ as a function of $C_{\mathrm{BLG}}\left(\mathrm{pH}\right.$ ); $C_{\mathrm{bl}}, \mathrm{C}_{\mathrm{t}}$, and $\mathrm{C}_{\mathrm{e}}$ are characteristic concentrations for formation and stability of NBFs (see details in the text), dotted line approximately indicates $\mathrm{C}_{\mathrm{e}}$, which divides the BLG concentration ranges for the formation of 'unstable' and 'stable' NBFs. Lines between symbols are guides to the eye.

The lowest film stability was observed for $\mathrm{pH} 3$ and $\mathrm{pH} 5$ at $\mathrm{C}_{\mathrm{BLG}}=10 \mu \mathrm{M}$, where the films ruptured soon after their formation at $\Pi=100-120 \mathrm{~Pa}$. At $\mathrm{pH} 3$ and $\mathrm{C}_{\mathrm{BLG}}=100 \mu \mathrm{M}$, the film stability was only slightly higher $\left(\Pi_{\mathrm{cr}}<1 \mathrm{kPa}\right)$ in full agreement with the disjoining pressure isotherm for such films reported earlier [61]. For $\mathrm{pH} 4,6$, and 7 at $\mathrm{C}_{\mathrm{BLG}}=10 \mu \mathrm{M}$, the film stability is higher (up to $\left.\Pi_{\mathrm{cr}}=1.6 \mathrm{kPa}\right)$. At $\mathrm{C}_{\mathrm{BLG}}=100 \mu \mathrm{M}, \Pi_{\mathrm{cr}}$ continuously increased with the $\mathrm{pH}$ and leveled off at $\mathrm{pH} 6$ and $\mathrm{pH} 7$, for which some of the most stable films did not rupture up to the highest measurable disjoining pressure of about $13 \mathrm{kPa}$ (experimental limit). 
At pH 5, where NBF type of foam films are directly formed at low disjoining pressures, we studied film stability also for two intermediate BLG concentrations, namely, $30 \mu \mathrm{M}$ and $70 \mu \mathrm{M}$. The $\Pi_{\mathrm{cr}}\left(\mathrm{C}_{\mathrm{BLG}}\right)$ dependence is presented in Figure 7b, and photos of such films are shown in Figure 5 and Figure $\mathrm{S} 6$ in the Supplementary Materials. The increase of $\mathrm{C}_{\mathrm{BLG}}$ from $10 \mu \mathrm{M}$ to $30 \mu \mathrm{M}$ led to much higher stability of the obtained NBFs, which ruptured at disjoining pressures in the range 5.5-7.1 kPa within the current experimental reproducibility. Further increase of $\mathrm{C}_{\mathrm{BLG}}$ to $70 \mu \mathrm{M}$ and $100 \mu \mathrm{M}$ led to a gradual increase of $\Pi_{\mathrm{cr}}$. It is obvious that the stabilization of the NBF structure (as studied at $\mathrm{pH} 5$ and $\mathrm{C}_{\text {buff }}=10 \mathrm{mM}$ ) occurs at protein concentrations in the range $10 \mu \mathrm{M}<\mathrm{C}_{\mathrm{BLG}}<30 \mu \mathrm{M}$. A critical surfactant concentration, denoted by $\mathrm{C}_{e}$ as the equilibrium concentration for the formation of a stable NBF, has been introduced earlier for foam and emulsion NBFs stabilized by low-molecular-weight surfactant as studied in a tube cell at relatively low disjoining pressures (usually below $140 \mathrm{~Pa}$ ); for example, $\mathrm{C}_{\mathrm{e}}=1.1 \mathrm{mM}$ for SDS solutions at $500 \mathrm{mM} \mathrm{NaCl}[64,65]$. Similar critical concentrations were also used for the characterization of the stability of black foam films of some proteins at $\mathrm{pH}$ values close to the isoelectric point; for example $24 \mu \mathrm{M}$ for lysozyme ( $\mathrm{pH} 10.5-11), 9 \mu \mathrm{M}$ for human serum albumin ( $\mathrm{pH}$ 4.9) and $15 \mu \mathrm{M}$ for bovine serum albumin ( $\mathrm{pH}$ 4.9) [67]. The present results for BLG show that such critical BLG concentration is of the same order of magnitude. Other characteristic concentrations introduced for surfactant films are, for example, the minimum surfactant concentration required for the formation of black spots in the films, denoted by $\mathrm{C}_{\mathrm{bl}}$, and the concentration, at which black films are always obtained, denoted by $C_{t}[64]$. We studied the probability of formation of (NBF) black spots in BLG foam films ( $\mathrm{pH}$ 5) obtained in a tube cell after aging the solution surfaces for $10 \mathrm{~min}$; the experimental conditions are explained in the Supporting Information, and the results are presented in Figure $7 \mathrm{~b}$ (also in Figure S6 in the Supplementary Materials). At $\mathrm{C}_{\mathrm{BLG}}=0.1 \mu \mathrm{M}$ black spots were not observed at all until film rupture, while at $\mathrm{C}_{\mathrm{BLG}}=1 \mu \mathrm{M}$ every film ruptured through the formation of black spots.

In summary, we found the characteristic concentrations of BLG for formation and stability of foam NBFs under the studied solvent conditions ( $\mathrm{pH} 5, \mathrm{C}_{\text {buff }}=10 \mathrm{mM}$ ): $0.1 \mu \mathrm{M}<\mathrm{C}_{\mathrm{bl}}<0.2 \mu \mathrm{M}$, $\mathrm{C}_{\mathrm{t}}=1 \mu \mathrm{M}$ and $10 \mu \mathrm{M}<\mathrm{C}_{\mathrm{e}}<30 \mu \mathrm{M}$. At the moment, we do not have information in which way small variations in $\mathrm{pH}$ and/or in salt concentration would affect these characteristic parameters. However, it was shown earlier that the addition of $\mathrm{NaCl}$ can improve the stability of BLG black films ( $\mathrm{pH}$ 5.3), presumably, due to salting-in effects [71].

\subsection{Foams}

Figure 8 presents results for the $t_{1 / 2}(\mathrm{pH}), \mathrm{t}_{\mathrm{dev}}(\mathrm{pH})$ and $\mathrm{t}_{\mathrm{tr}}(\mathrm{pH})$ dependencies for foams obtained from BLG solutions at the two studied BLG concentrations of $10 \mu \mathrm{M}$ and $100 \mu \mathrm{M}$. It has been found earlier for surfactant foams that there is a linear relation between $t_{1 / 2}$ and $t_{\text {tr }}$ [16]. This is also the case for the present results for BLG foams. Combining the data in Figures $8 b$ and $9 b$ results in a linear $t_{1 / 2}$ $\sim 0.75 \mathrm{t}_{\mathrm{tr}}$ dependence, which is presented in Figure S3 in the Supplementary Materials. Hence, in our further discussion, we do not consider these parameters separately and will focus on the results for $t_{t r}$. In contrast, the corresponding values for $t_{\mathrm{dev}}$ are two orders of magnitude lower. The data for the two dependences $t_{\operatorname{dev}}(\mathrm{pH})$ and $t_{\operatorname{tr}}(\mathrm{pH})$ for the two BLG concentrations follow rather similar trends with an offset to longer characteristic times for the higher $\mathrm{C}_{\mathrm{BLG}}$; however, some peculiarities were observed, and they are discussed in Section 4. Obviously, the general foam stability is reflected by all of the three used parameters in a similar manner, hence in the following, we use the term 'foam stability' as a generalization for all foam results and where appropriate we discuss the individual types of foam (characteristic time) data. 

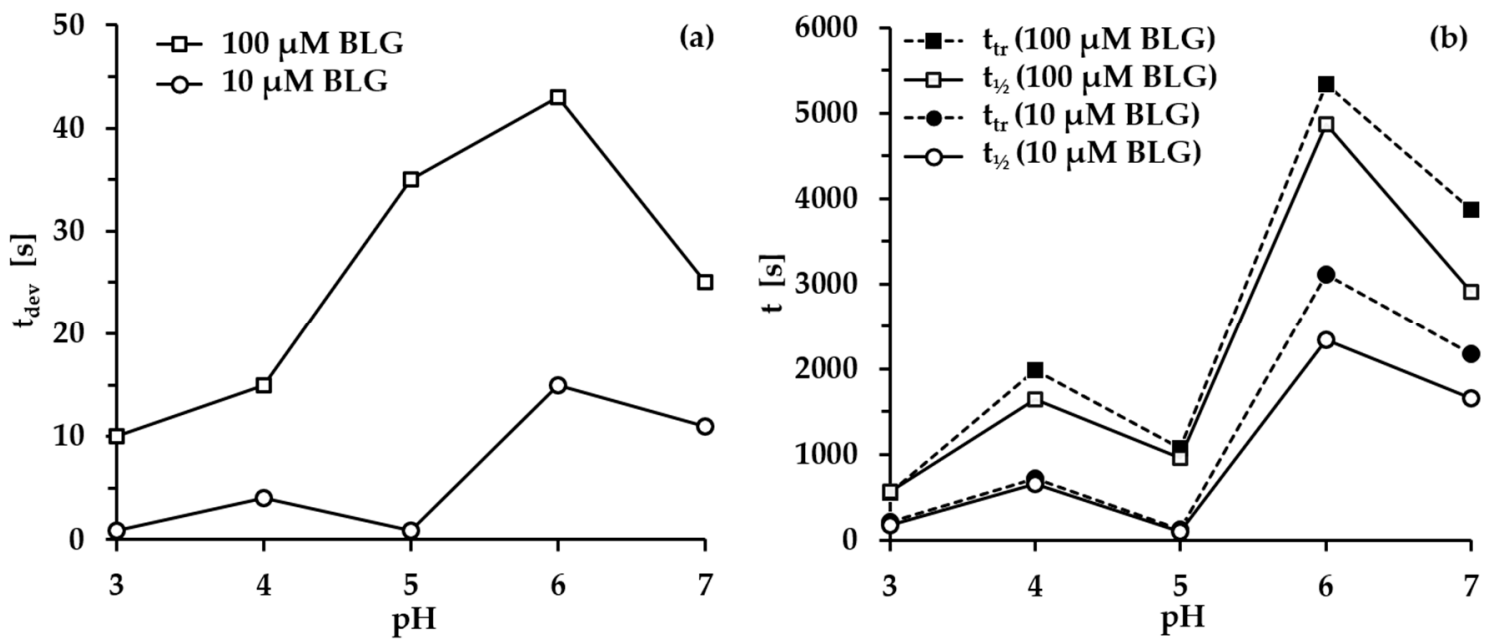

Figure 8. Characteristic times (a) $t_{\mathrm{dev}}$, (b) $t_{1 / 2}$ and $t_{\mathrm{tr}}$, for foams obtained from solutions at two BLG concentrations of $10 \mu \mathrm{M}$ and $100 \mu \mathrm{M}$ and various $\mathrm{pH}\left(\mathrm{C}_{\text {buff }}=10 \mathrm{mM}\right)$. Lines are guides to the eye. Each data point is one foam experiment.
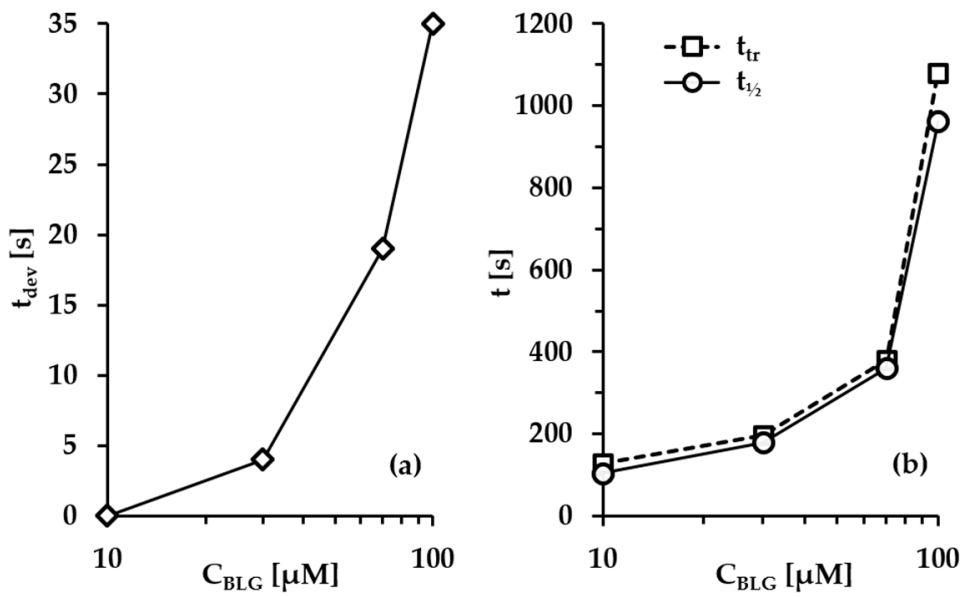

Figure 9. Characteristic times (a) $t_{d e v}$, (b) $t_{1 / 2}$ and $t_{t r}$, of foam decay as a function of $C_{B L G}\left(p H 5, C_{b u f f}\right.$ $=10 \mathrm{mM}$ ). Lines are guides to the eye. Each data point is one foam experiment.

At $\mathrm{C}_{\mathrm{BLG}}=10 \mu \mathrm{M}$, there is a slight increase in foam stability from $\mathrm{pH} 3$ to 4 , and then it decreases to a minimum at $\mathrm{pH} 5$ (isoelectric point, $\mathrm{pI} \approx 5.1$ ). This comparatively very low foam stability is in correspondence with the foam film data in Figure 7 and with previous results [61], which all show the formation of black films with extremely low stability at $\mathrm{C}_{\mathrm{BLG}}=10 \mu \mathrm{M}$ and $\mathrm{pH} \rightarrow \mathrm{pI}$. Further increase of $\mathrm{pH}$ to 6 and 7 leads to a significantly increased foam stability. At $\mathrm{C}_{\mathrm{BLG}}=100 \mu \mathrm{M}$, a general increase in foam stability was observed and as mentioned above the trend remains virtually the same. A very similar trend of the $t_{1 / 2}(\mathrm{pH})$ dependence was reported for foams obtained from solutions with $\mathrm{C}_{\mathrm{BLG}} \approx 27 \mu \mathrm{M}$ (intermediate between those used in our experiments) and comparable buffer concentrations [25]. Interestingly, those authors also found a decrease in the half-lifetime of foams at $\mathrm{pH}$ 3 and $\mathrm{pH} 7$ with a further increase of the BLG concentration to about $270 \mu \mathrm{M}$, and reported the existence of a maximum in the $\mathrm{t}_{1 / 2}\left(\mathrm{C}_{\mathrm{BLG}}\right)$ dependence for these $\mathrm{pH}$ values, while at $\mathrm{pH} 5, \mathrm{t}_{1 / 2}$ monotonically increases with the protein concentration as also revealed by our data in Figure 9. The latter trend is in agreement with the increased stability of the NBFs (at pH 5) with increasing $\mathrm{C}_{\mathrm{BLG}}$ (Figure $7 \mathrm{~b}$ ), while the observed decrease in foam stability with increase of the BLG concentration [25] does not correlate with the increase in the foam film stability found in our work here. 
In the special case of foams at $\mathrm{pH} 5$, the effect of increasing BLG concentration from $10 \mu \mathrm{M}$ to $100 \mu \mathrm{M}$ is the strongest and changes the shape of the $t_{\mathrm{dev}}(\mathrm{pH})$ dependence (Figure $\left.8 \mathrm{a}\right)$. Figure 9 presents measured $t_{d e v}\left(C_{B L G}\right)_{p H 5}, t_{1 / 2}\left(C_{B L G}\right)_{p H 5}$ and $t_{t r}\left(C_{B L G}\right)_{p H 5}$ dependencies. In all cases, a gradual increase in the foam stability was observed with increasing $C_{B L G}$.

To better illustrate the interrelations between the stabilities of single foam films and macroscopic foams, we plotted in Figure 10 the measured characteristic times $t_{d e v}\left(\mathrm{pH}, \mathrm{C}_{\mathrm{BLG}}\right)$ and $\mathrm{t}_{\mathrm{tr}}\left(\mathrm{pH}, \mathrm{C}_{\mathrm{BLG}}\right)$ of the foam decay taken from Figures 8 and 9 against the corresponding film critical pressures $\Pi_{\mathrm{cr}}(\mathrm{pH}$, $\mathrm{C}_{\mathrm{BLG}}$ ) taken from Figure 7 . We also estimated the approximate values of the capillary pressures $\mathrm{P}_{\mathrm{C}, \mathrm{F}}$ in the studied foams on the basis of literature data for the Sauter mean bubble radii $\mathrm{r}_{32}$ in foams obtained in BLG solutions at different $\mathrm{C}_{\mathrm{BLG}}$ and $\mathrm{pH}[25,37]$. The calculations, presented in the SI, yielded a spectrum of estimated capillary pressures between minimum $\mathrm{P}_{\mathrm{c}, \mathrm{F}}^{\mathrm{min}} \approx 170 \mathrm{~Pa}$ and maximum $\mathrm{P}_{\mathrm{c}, \mathrm{F}}^{\max } \approx 1.7 \mathrm{kPa}$ values (indicated as dashed lines in Figure 10) for all studied foams.
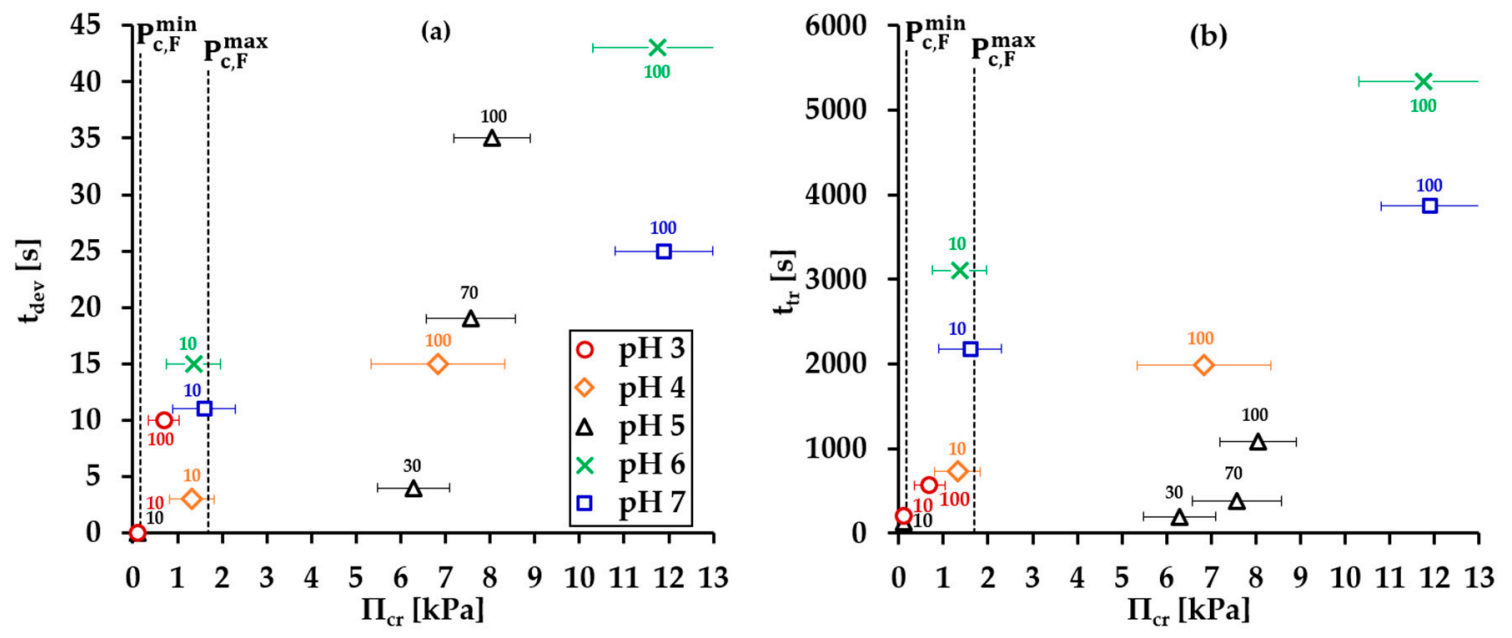

Figure 10. Characteristic times (a) $t_{\mathrm{dev}}$ and (b) $t_{\mathrm{tr}}$ of foam decay as a function of the critical pressure of rupture $\Pi_{\text {cr }}$ of single foam films. The vertical dashed lines indicate the range of estimated foam capillary pressures $P_{c, F}$ as explained in the text. Numbers indicate the BLG concentration $[\mu \mathrm{M}]$.

\section{Discussion}

The BLG concentrations of $10 \mu \mathrm{M}$ and $100 \mu \mathrm{M}$ used in the experiments were chosen in order to cover a range of foam half-lifetimes from few minutes to hours depending on the solution $\mathrm{pH}$. Half-lifetime of foams, as well as some interfacial characteristics of BLG solutions, were previously studied by Lech et al. [25] as affected by $\mathrm{pH}$ at very similar solvent conditions and at several $\mathrm{C}_{\mathrm{BLG}}$ - therefore, a helpful comparison with our results can be made. In the following, we discuss the decay of a BLG foam column on the basis of the stability of corresponding foam films. Important dynamical, electrical, rheological and structural characteristics of foam interfaces and foam films that affect foam properties are hardly accessible by probing foams in situ, therefore, the usual model systems used are a single isolated interface or film. Although those are compromise options, they are practically the most commonly used. The 'compromise' comes from the facts that, on the one hand, the foam is a dynamic (eventually quasi-static at hydrostatic equilibrium) system and interfaces and films can be to a different extent close to equilibrium. On the other hand, a single interface or film is usually investigated under well-defined conditions. In contrast, the lamellae and interfaces in the foam can experience the simultaneous action of several factors (so-called 'collective effects' $[4,10,18,54]$ ), which cannot be reflected in single film experiments. However, good correlations between the foam film and foam stabilities were found in the present study, and we discuss these in more detail in the following.

Firstly, we briefly consider the pH-dependent adsorption kinetics of BLG at water-air interfaces. It is commonly accepted that fast surfactant adsorption kinetics is the most important prerequisite 
for foam generation $[10,13,31]$. Adsorption of surface-active substances and formation of dynamic adsorption layers (DAL) take place during the formation and growth of bubbles, as well as during their rising in solution $[10,23,72]$. Figure S7 in the Supplementary Materials shows that the 'short-time' adsorption kinetics (0.1-80 s as relevant to the time-scale of foam formation) in the studied solutions is relatively fast for $\mathrm{pH}$ values in the range $4-7$, while for $\mathrm{pH} 3$ it is slower (however significantly improved at the higher $\mathrm{C}_{\mathrm{BLG}}$ ). Rising bubbles in such solutions are supposed to be fully retarded, since the rising bubble velocity technique becomes insensitive for $\mathrm{C}_{\mathrm{BLG}}>5 \mu \mathrm{M}$ BLG in the $\mathrm{pH}$ range 3-7 [62]. This means that a DAL of BLG is readily formed at the bubble surface in any of the solutions investigated in the present study, however, the exact adsorbed amounts are unknown. Further, longer-time adsorption experiments revealed the tendency that $\mathrm{pH}$-dependent interfacial characteristics of proteins usually exhibit extremum around pI, where an interfacial charge reversal occurs [35]; for example for BLG the surface pressure (Figure S8 in the Supplementary Materials) and the surface excess $[35,58,60]$, as well as the surface shear elastic and viscous moduli [56], are maximal at $\mathrm{pH} 5$ ( $\mathrm{pH}$ range 3-7). All these can be related to the formation of thick heterogeneous BLG adsorption layers ( $\mathrm{pH} 5$ ) with the occurrence of a loose secondary sublayer of disordered BLG dimers adjacent to the dense primary monolayer as resolved by neutron reflectometry experiments [60].

It is somewhat intriguing that the above considered $\mathrm{pH}$-dependent interfacial properties of BLG contravene the trend in foam stability, which we will discuss in more detail based on the foam film results. Inspecting Figure 10 one can see that the $t_{\text {dev }}\left(\Pi_{\mathrm{cr}}\right)$ and $t_{\mathrm{tr}}\left(\Pi_{\mathrm{cr}}\right)$ data can be separated into three groups according to the estimated range of foam capillary pressures $\mathrm{P}_{\mathrm{c}, \mathrm{F}}$; a fourth group is assigned to the special case of films and foams at $\mathrm{pH} 5$ :

1. Group 1: $\Pi_{\mathrm{cr}}<\mathrm{P}_{\mathrm{c}, \mathrm{F}}^{\mathrm{min}}$. This condition is valid for the foams and films at $\mathrm{pH} 3$ and $\mathrm{pH} 5$ and at $\mathrm{C}_{\mathrm{BLG}}=10 \mu \mathrm{M}$, and can explain the lack of measurable $\mathrm{t}_{\mathrm{dev}}$ values, where it is possible that the onset of bubble coalescence occurs already in the period of foam formation. These two foams also exhibit the shortest $t_{1 / 2}$ and $t_{t r}$ (in the order of some minutes). For $\mathrm{pH} 5$, this is somehow expected, having in mind that $\mathrm{C}_{\mathrm{BLG}}=10 \mu \mathrm{M}<\mathrm{C}_{\mathrm{e}}$ and unstable NBF spots emerge in films within seconds (Figure S6 in the Supplementary Materials). For pH 3, the most probable reason is low protein surface excess as suggested by the long induction time in the dynamic surface pressure measurements (Figures S6 and S7 in SI).

2. Group 2: $\mathrm{P}_{\mathrm{c}, \mathrm{F}}^{\min }<\Pi_{\mathrm{cr}}<\mathrm{P}_{\mathrm{c}, \mathrm{F}}^{\max }$. This condition is valid for the foams and films at $\mathrm{pH} 4,6,7$ and $\mathrm{C}_{\mathrm{BLG}}$ $=10 \mu \mathrm{M}$, but also for those at $\mathrm{pH} 3$ and $\mathrm{C}_{\mathrm{BLG}}=100 \mu \mathrm{M}$, and results in measurable values for $t_{\mathrm{dev}}$. We should mention here that the time scale of $t_{\mathrm{dev}}$ is much shorter than the typical timescale of protein foam film drainage [19,20,61,67-71] (Figures 3 and 6). Therefore, bubble coalescence seemingly takes place for films that are far from equilibrium, which is highly probable for bubbles in the top foam layer of a freshly produced foam [73]. Despite the higher protein concentration at $\mathrm{pH} 3$, foam and film stabilities are still relatively low, and the reason for that is not clear yet [25]. Nevertheless, the good film-foam correlations in groups 1 and 2 demonstrate that single foam film stability is an indicator of foam stability. However, this is not the case for the foams in group 3.

3. Group 3: $\Pi_{\mathrm{cr}}>\mathrm{P}_{\mathrm{c}, \mathrm{F}}$. This condition is valid for the foams and films at $\mathrm{pH} 4-7$ and $\mathrm{C}_{\mathrm{BLG}}=100 \mu \mathrm{M}$ (as well as for intermediate $\mathrm{C}_{\mathrm{BLG}}$ at $\mathrm{pH}$ ) and suggests higher resistance of the foam bubbles to coalescence. Indeed, $t_{\mathrm{dev}}$ and $t_{t r}$ increase, which agrees with the results in ref. [17]. This fact should be related mainly to the increased protein surface excess at the foam interfaces (as known from adsorption studies $[58,60]$ ) that leads to at least two important contributions: (i) stronger immobilization of interfaces, which decelerates the liquid efflux [10,28]; and (ii) stabilization of foam films against rupture $[61,71]$, i.e., impact on the processes of syneresis and coalescence, respectively. The longest $t_{d e v}$ at $\mathrm{pH} 5,6,7$ are attributable to the low calculated rates of liquid efflux $v_{\text {dev }}$ (Equations (S1)) and Figure S4 in the Supplementary Materials) in the initial stage of foam decay $\left(\mathrm{t}_{0}-\mathrm{t}_{\text {dev }}\right)$; the longest $\mathrm{t}_{\mathrm{tr}}$ at $\mathrm{pH} 6$ and $\mathrm{pH} 7$ correspond to the most stable foam films. Concerning the latter, we should note that despite the comparable film stability at $\mathrm{pH} 6$ and $\mathrm{pH} 7$, foam stability diminishes at $\mathrm{pH} 7$. 
4. Group 4: $\Pi_{\mathrm{cr}}>\mathrm{P}_{\mathrm{c}, \mathrm{F}}^{\max } ; \mathrm{pH}$ 5. At $\mathrm{C}_{\mathrm{BLG}}>\mathrm{C}_{\mathrm{e}}, \Pi_{\mathrm{cr}}$ continuously increases with increasing $\mathrm{C}_{\mathrm{BLG}}$ resulting in increasing foam stability [25]. At $\mathrm{C}_{\mathrm{BLG}}=100 \mu \mathrm{M}, \Pi_{\mathrm{cr}}$ for $\mathrm{pH} 5$ and $\mathrm{pH} 4$ are comparable (within the experimental error), but at $\mathrm{pH} 5$ the measured $\mathrm{t}_{\mathrm{dev}}$ is almost two-fold longer, whereas $t_{t r}$ is shorter. While the latter cannot be straightforwardly explained, the former can be attributed to the much lower $\mathrm{v}_{\operatorname{dev}}$ (Figure $S 4$ in the Supplementary Materials) as a result of the high surface viscosities either in shear [56] or in dilation [59] (Figure S8 in the Supplementary Materials) as measured at early times of adsorption, as well as from a cork effect in the Plateau borders [24], and entrapment of BLG aggregates in the films (Figure 5). Hence, the foam at pH 5 drains slower than that at $\mathrm{pH} 4$, but the rate of bubble coalescence is higher and a possible explanation for that should be due to the influence of aggregates. It has been shown that foams obtained from mixed dispersions of native and aggregated BLG can be either less or more stable than foams from pure native BLG solutions, and the direction of change of foam stability depends on both the aggregate size and the ratio of native/aggregated entities [24].

The pressure condition $\Pi_{\mathrm{cr}}>\mathrm{P}_{\mathrm{c}, \mathrm{F}}^{\max }$ (groups 3 and 4) opens the question about the driving force for the observed foam destruction. After $t_{\mathrm{dev}}$, the foam decay is determined not only by syneresis, but also by progressive coalescence of bubbles in the top foam layer $[10,73]$ with a maximum rate at $t_{t r}$. At the same time, bubble disproportionation (foam coarsening) is expected to take place in the foam. It has been shown that the coarsening rate in protein foams is lower than that in surfactant foams [19], which can be reasonably accounted for with lower permeability coefficients for protein films [71]. Coarsening generally leads to an overall increase in the bubble size. Hence, with time, the newly appeared top foam layers consist of bubbles with progressively increasing sizes, which causes a decrease of $\mathrm{P}_{\mathrm{c}, \mathrm{F}}$, but at the same time, the probability for film rupture increases, due to increased film area $[4,53]$. A possible driving force for rupture of external foam films in the top foam layer is the intensive evaporation of water, since these films are exposed to the ambient atmosphere. Furthermore, the action of "collective effects" in foam has been recognized as a strong destabilizing factor $[4,10,18]$.

To further our discussion, particularly towards the effect of $\mathrm{pH}$, we should once again emphasize the relatively good correlation between the stabilities of foams and single foam films. The major feature of the presented results is the lower film and foam stabilities at $\mathrm{pH}<\mathrm{pI}$ as compared to those at $\mathrm{pH}>\mathrm{pI}$, with the extreme case of $\mathrm{pH} 3$, where foam stability could not be much improved even at a BLG concentration as high as $\sim 1100 \mu \mathrm{M}$ [25]. A comparison of adsorption and dilational rheology results shows rather similar behaviors for BLG solutions at pH 4, 6, 7 (Figures S6 and S7 in SI) [25,61]. From the viewpoint of surface forces, film thickness measurements did not give any indications to support such a trend in the stability of BLG films $[25,61]$. Furthermore, disjoining pressure isotherm study revealed that BLG foam films at $\mathrm{pH} 3.5$ and $\mathrm{pH} 7$ have similar (intermediate) stability at a low buffer concentration of $C_{\text {buff }}=3 \mathrm{mM}$, but at $C_{\text {buff }}=10 \mathrm{mM}$, the stability of the obtained black films increases for $\mathrm{pH} 7$ and decreases for $\mathrm{pH} 3.5$ [25,61]. It is obvious that neither surface properties nor electrostatic interactions could satisfactorily explain the observed $\mathrm{pH}$-dependent film behavior.

The rupture of symmetric thin liquid film stabilized by a low-molecular-weight surfactant can happen through different mechanisms depending on the film thickness, e.g., the fluctuation waves approach for the case of thick films $(>30 \mathrm{~nm}$ ) or the hole-nucleation approach for the case of amphiphile bilayers (NBF and bilayer lipid membrane) $[4,64,65]$. However, these theories have been developed based on experiments with films at constant low disjoining pressure, and this is not clear yet whether they are applicable to describe the rupture of 'stable' films at the critical pressure. So far, to the best of our knowledge, there is not any theory, which considers the case of protein films. Having in mind the almost irreversible adsorption of proteins at liquid interfaces and the pronounced viscoelastic behavior of the corresponding interfacial layers, the phenomenon of rupture of protein black films could obey other mechanisms. Very recently, it was shown for mixed polymer/surfactant aqueous systems that resolving the molecular structure of the adsorbed interfacial layers is a vital step for revealing the surface forces operative in the corresponding foam films, and thus, the film stabilization 
mechanism [74]. Therefore, looking deeper into the structure of protein layers would give more insight into the stability of protein black films.

In solutions with $\mathrm{pH}$ near $\mathrm{pI}, \mathrm{BLG}$ exists exclusively as a dimer, which dissociates into monomers by moving the $\mathrm{pH}$ away from $\mathrm{pI}$; in BLG solutions at $\mathrm{pH} 3$ the monomer is favored, while at $\mathrm{pH} 4,6$ and 7 the dimer is favored [75-80]. In the $\mathrm{pH}$ range $3-7$, the $\mathrm{pH}$ causes relatively weak effects on the secondary and tertiary structures of BLG in solution bulk, and its general conformation is believed to be retained to a certain extent. However, two major structure transitions have been identified [76]: (i) the $\mathrm{pH} 2.5-4$ transition (slight change in secondary and tertiary structures) accompanied by the formation of dimer; and (ii) the $\mathrm{pH}$ 4.5-6 transition (slight change in tertiary structure). Adsorption of BLG monomers and dimers at the water/air interface of solutions at $\mathrm{pH} 3,5$ and 7 were examined via surface excess and layer thickness measurements by neutron reflectometry [60]. At $\mathrm{pH} 3$ and $\mathrm{pH}$ 7 the formation of dense monolayers with similar thicknesses $(\sim 1.1 \mathrm{~nm})$ was found that consist of flattened BLG globules independent of the fractions of dimers and monomers in the bulk solution. However, any effects of the BLG secondary and/or tertiary structures were not recognized. In another study, SFG spectroscopy experiments revealed that water molecules at the vicinity of BLG covered interfaces form more ordered networks at $\mathrm{pH}<\mathrm{pI}$ than at $\mathrm{pH}>\mathrm{pI}$ [35], which could originate from structural specificities of adsorbed BLG entities. It is somewhat intriguing that the trend of the foam film stability with increasing $\mathrm{pH}(3-7)$ somehow reflects the $\mathrm{pH}$-induced transitions in the molecular structure of BLG in bulk, as well as the different structuring of interfacial water. At the same time, the "monomer-dimer concept" could not give a satisfactory explanation of these findings.

\section{Concluding Comments and Outlook}

A good correlation between the stabilities of black foam films and foams obtained for BLG solutions at various $\mathrm{pH}$ values (3-7) was found that can be very useful for predicting the stability of protein foams and designing strategies for foam control in applications. This also shows that precisely the critical disjoining pressure of film rupture rather than the film thickness seems to a great extent to be determinant for foam stability. More profound quantitative analysis on the protein foams of interest requires the application of additional methods, for example, the foam pressure drop technique, which allows control over the foam capillary pressure $[4,18,52,53]$.

The comparison of the obtained results to key BLG interfacial properties appeared intricate, thereby, robust interrelations could not be identified. Adsorption and surface viscoelasticity characteristics, which exhibit maximum values around $\mathrm{pI}[25,35,56,58-60]$, cannot explain the trend of increasing film stability with increasing $\mathrm{pH}$. The most striking example is the remarkably low film and foam stabilities at $\mathrm{pH} 3$, even at very high BLG concentrations [25]. Resolving the molecular structure of interfacial protein layers must be a promising strategy to understand the phenomenon of rupture of protein black films at the critical disjoining pressure. Since the thickness of BLG monolayers is almost independent of $\mathrm{pH}$ ([60] and references therein), one should investigate in greater detail eventual $\mathrm{pH}$-induced changes in the molecular (tertiary) structure of adsorbed BLG (dimer/monomer) entities in order to reveal the mechanism of film rupture. Some insights into possible mechanisms could be gained by attempting to apply the hole-nucleation theory developed for the description of the mechanism of rupture of low-molecular-weight amphiphilic bilayers $[4,64,65]$ to protein bilayers $[61,81]$ obtained at constant low disjoining pressure (such data are shown in Figure 7b). However, the comparison of experimental data on protein bilayers with that theory can be complicated, due to the pronounced viscoelastic behavior of interfacial protein layers.

Supplementary Materials: The following are available online at http://www.mdpi.com/2075-163X/10/7/636/s1, Figure S1: titration curves and zeta potential, Figure S2: $\Delta \mathrm{H}_{\mathrm{F}}$ vs. $\Delta \mathrm{H}_{\mathrm{L}}$ plot for an exemplary foam, Figure S3: $\mathrm{t}_{1 / 2}$ vs $t_{t r}$ plot of the data in Figures $8 b$ and $9 b$, Figure S4: $v_{\text {dev }}$ vs. pH, Figure S5: scheme of the Scheludko-Exerowa tube cell, Figure S6: $W_{\text {bs }}$ vs. $C_{\text {BLG }}(\mathrm{pH} 5)$, Figure S7: kinetic dependencies of the surface pressure, Figure S8: kinetic dependencies of the surface pressure and dilational viscoelasticity modulus. 
Author Contributions: Conceptualization, G.G.G., V.U. and R.M.; methodology, G.G.G., V.U. and I.R.; software, G.G.G. and V.U.; investigation, G.G.G., V.U., I.R. and R.M.; resources, U.K. and B.B.; writing-original draft preparation, G.G.G. and V.U.; writing—review and editing, G.G.G., V.U., C.G.-D., D.Z.G., M.L., U.K., R.M. and B.B.; visualization, G.G.G. and V.U.; supervision, G.G.G. and R.M.; funding acquisition, C.G.-D., D.Z.G., M.L., U.K., R.M. and B.B. All authors have read and agreed to the published version of the manuscript.

Funding: This work was financially supported by Nestlé Research Center, Lausanne and by a DFG-AiF cluster project on "Protein Foams" Mi418/20-1 (DFG-199448917). G.G.G. and B.B. gratefully acknowledge financial support by the European Research Council (ERC) under the European Union's Horizon 2020 research and innovation program (grant agreement No 638278).

Acknowledgments: We sincerely thank Daniel Baier and Cornelia Rauh from Technical University of Berlin, Germany for allowing us to use the lab facilities and the Krüss ${ }^{\circledR}$, DFA-100 instrument.

Conflicts of Interest: The authors declare no conflict of interest.

\section{References}

1. Vignes-Adler, M. Historical Perspectives of Foams. In Foam Films and Foams: Fundamentals and Applications; Exerowa, D., Gochev, G., Platikanov, D., Liggieri, L., Miller, R., Eds.; CRC Press: Boca Raton, FL, USA, 2018; Chapter 8.

2. Gochev, G.; Ulaganathan, V.; Miller, R. Foams. Ullmann's Encyclopedia of Industrial Chemistry; Wiley-VCH: Weinheim, Germany, 2016; pp. 1-31.

3. Bikerman, J.J. Foams; Springer: New York, NY, USA, 1973.

4. Exerowa, D.; Kruglyakov, P.M. Foam and Foam Films; Elsevier: Amsterdam, The Netherlands, 1998.

5. Cantat, I.; Cohen-Addad, S.; Elias, F.; Graner, F.; Höhler, R.; Pitois, O.; Rouyer, F.; Saint-Jalmes, A.; Cox, S. Foams: Structure and Dynamics; OUP: Oxford, UK, 2013.

6. Pugh, R. Bubble and Foam Chemistry; CUP: Cambridge, UK, 2016.

7. Langevin, D. Foam stabilization Mechanisms. In Foam Films and Foams: Fundamentals and Applications; Exerowa, D., Gochev, G., Platikanov, D., Liggieri, L., Miller, R., Eds.; CRC Press: Boca Raton, FL, USA, 2018; Chapter 11.

8. Schmidt, C.G.; Gunez, D.Z.; Gehin-Delval, C.; Leser, M.E. Protein-Stabilized Foams. In Foam Films and Foams: Fundamentals and, Applications; Exerowa, D., Gochev, G., Platikanov, D., Liggieri, L., Miller, R., Eds.; CRC Press: Boca Raton, FL, USA, 2018; Chapter 14.

9. Murray, B.S. Stabilization of bubbles and foams. Curr. Opin. Colloid Interface Sci. 2007, 12, 232-241. [CrossRef]

10. Malysa, K.; Lunkenheimer, K. Foams under dynamic conditions. Curr. Opin. Colloid Interface Sci. 2008, 13, 150-162. [CrossRef]

11. Langevin, D. Aqueous foams: A field of investigation at the frontier between chemistry and physics. Chem. Phys. Chem. 2008, 9, 510-522. [CrossRef] [PubMed]

12. Wierenga, P.A.; Gruppen, H. New views on foams from protein solutions. Curr. Opin. Colloid Interface Sci. 2010, 15, 365-373. [CrossRef]

13. Wang, J.; Nguyen, A.V.; Farrokhpay, S. A critical review of the growth, drainage and collapse of foams. Adv. Colloid Interface Sci. 2016, 228, 55-70. [CrossRef]

14. Narsimhan, G.X.; Xiang, N. Role of Proteins on Formation, Drainage, and Stability of Liquid Food Foams. Ann. Rev. Food Sci. Technol. 2018, 25, 45-63. [CrossRef]

15. Drenckhan, W.; Saint-Jalmes, A. The science of foaming. Adv. Colloid Interface Sci. 2015, 222, 228-259. [CrossRef]

16. Lunkenheimer, K.; Malysa, K.; Winsel, K.; Geggel, K.; Siegel, S. Novel Method and Parameters for Testing and Characterization of Foam Stability. Langmuir 2009, 26, 3883-3888. [CrossRef]

17. Álvarez Gómez, J.M.R.P.; Rodríguez Patino, J.M. Formulation Engineering of Food Model Foams Containing Diglycerol Esters and $\beta$-Lactoglobulin. Ind. Eng. Chem. Res. 2006, 45, 7510-7519. [CrossRef]

18. Stubenrauch, C.; Khristov, K. Foams and foam films stabilized by $C_{n} T A B$ : Influence of the chain length and of impurities. J. Colloid Interface Sci. 2005, 286, 710-718. [CrossRef]

19. Saint-Jalmes, A.; Peugeot, M.-L.; Ferraz, H.; Langevin, D. Differences between protein and surfactant foams: Microscopic properties, stability and coarsening. Colloids Surf. A 2005, 263, 219-225. [CrossRef]

20. Maldonado-Valderrama, J.L.; Langevin, D. On the Difference between Foams Stabilized by Surfactants and Whole Casein or $\beta$-Casein. Comparison of Foams, Foam Films, and Liquid Surfaces Studies. J. Phys. Chem. $B$ 2008, 112, 3989-3996. [CrossRef] [PubMed] 
21. Alahverdjieva, V.S.; Khristov, K.; Exerowa, D.; Miller, R. Correlation between adsorption isotherms, thin liquid films and foam properties of protein/surfactant mixtures: Lysozyme/ ${ }_{10} \mathrm{DMPO}$ and lysozyme/SDS. Colloids Surf. A 2008, 323, 132-138. [CrossRef]

22. Wierenga, P.A.; van Norél, L.; Basheva, E.S. Reconsidering the importance of interfacial properties in foam stability. Colloids Surf. A 2009, 344, 72-78. [CrossRef]

23. Zawala, J.; Todorov, R.; Olszewska, A.; Exerowa, D.; Malysa, K. Influence of pH of the BSA solutions on velocity of the rising bubbles and stability of the thin liquid films and foams. Adsorption 2010, 16, 423-435. [CrossRef]

24. Rullier, B.; Axelos, M.A.V.; Langevin, D.; Novales, B. $\beta$-Lactoglobulin aggregates in foam films: Effect of the concentration and size of the protein aggregates. J. Colloid Interface Sci. 2010, 343, 330-337. [CrossRef]

25. Lech, F.J.; Delahaije, R.J.B.M.; Meinders, M.B.J.; Gruppen, H.; Wierenga, P.A. Identification of critical concentrations determining foam ability and stability of $\beta$-lactoglobulin. Food Hydrocoll. 2016, 57, 46-54. [CrossRef]

26. Lech, F.J. Foam Properties of Proteins, Low Molecular Weight Surfactants and Their Complexes. Ph.D. Thesis, Wageningen University, Wageningen, The Netherlands, 2016.

27. Braunschweig, B.; Schulze-Zachau, F.; Nagel, E.; Engelhardt, K.; Stoyanov, S.; Gochev, G.; Khristov, K.; Mileva, E.; Exerowa, D.; Miller, R.; et al. Specific effects of $\mathrm{Ca}^{2+}$ ions and molecular structure of $\beta$-lactoglobulin interfacial layers that drive macroscopic foam stability. Soft Matter 2016, 12, 5995-6004. [CrossRef]

28. Prins, A. Stagnant surface behaviour and its effect on foam and film stability. Colloids Surf. A 1999, 149, 467-473. [CrossRef]

29. Krasowska, M.; Hristova, E.; Khristov, K.; Malysa, K.; Exerowa, D. Isoelectric state and stability of foam films, bubbles and foams from PEO-PPO-PEO triblock copolymer (P-85). Colloid Polym. Sci. 2006, 284, 475-481. [CrossRef]

30. Beneventi, D.; Carre, B.; Gandini, A. Role of surfactant structure on surface and foaming properties. Colloids Surf. A 2001, 189, 65-73. [CrossRef]

31. Martin, A.H.; Grolle, K.; Bos, M.A.; Stuart, M.A.C.; van Vliet, T. Network forming properties of various proteins adsorbed at the air/water interface in relation to foam stability. J. Colloid Interface Sci. 2002, 254, 175-183. [CrossRef]

32. Maldonado-Valderrama, J.; Martín-Rodriguez, A.; Gálvez-Ruiz, M.J.; Miller, R.; Langevin, D.; Cabrerizo-Vílchez, M.A. Foams and emulsions of $\beta$-casein examined by interfacial rheology. Colloids Surf. A 2008, 323, 116-122. [CrossRef]

33. Blijdenstein, T.B.J.; de Groot, P.W.N.; Stoyanov, S.D. On the link between foam coarsening and surface rheology: Why hydrophobins are so different. Soft Matter 2010, 6, 1799-1808. [CrossRef]

34. Dimitrova, L.M.; Petkov, P.V.; Kralchevsky, P.A.; Stoyanov, S.D.; Pelan, E.G. Production and characterization of stable foams with fine bubbles from solutions of hydrophobin HFBII and its mixtures with other proteins. Colloids Surf. A 2017, 521, 92-104. [CrossRef]

35. Engelhardt, K.; Lexis, M.; Gochev, G.; Konnerth, C.; Miller, R.; Willenbacher, N.; Peukert, W.; Braunschweig, B. $\mathrm{pH}$ Effects on the Molecular Structure of $\beta$-Lactoglobulin Modified Air-Water Interfaces and Its Impact on Foam Rheology. Langmuir 2013, 29, 11646-11655. [CrossRef] [PubMed]

36. Lexis, M.; Willenbacher, N. Yield stress and elasticity of aqueous foams from protein and surfactant solutions - The role of continuous phase viscosity and interfacial properties. Colloids Surf. A 2014, 459, 177-185. [CrossRef]

37. Lexis, M.; Willenbacher, N. Relating foam and interfacial rheological properties of $\beta$-lactoglobulin solutions. Soft Matter 2014, 10, 9626-9636. [CrossRef]

38. Willenbacher, N.; Lexis, M. Foam Rheology. In Foam Films and Foams: Fundamentals and Applications; Exerowa, D., Gochev, G., Platikanov, D., Liggieri, L., Miller, R., Eds.; CRC Press: Boca Raton, FL, USA, 2018; Chapter 17.

39. Wan, Z.; Yang, X.; Sagis, L.M.C. Contribution of Long Fibrils and Peptides to Surface and Foaming Behavior of Soy Protein Fibril System. Langmuir 2016, 32, 8092-8101. [CrossRef]

40. Peng, D.; Yang, J.; Li, J.; Tang, C.; Li, B. Foams Stabilized by $\beta$-Lactoglobulin Amyloid Fibrils: Effect of $\mathrm{pH}$. J. Agric. Food Chem. 2017, 65, 10658-10665. [CrossRef] 
41. Hu, J.; Yang, J.; Xu, Y.; Zhang, K.; Nishinari, K.; Phillips, G.O.; Fang, Y. Comparative study on foaming and emulsifying properties of different beta-lactoglobuline aggregates. Food Funct. 2019, 10, 5922-5930. [CrossRef] [PubMed]

42. Dombrowski, J.; Dechau, J.; Kulozik, U. Multiscale approach to characterize bulk, surface and foaming behavior of casein micelles as a function of alkalinisation. Food Hydrocoll. 2016, 57, 92-102. [CrossRef]

43. Dombrowski, J.; Johler, F.; Warncke, M.; Kulozik, U. Correlation between bulk characteristics of aggregated $\beta$-Lactoglobulin and its interfacial foaming properties. Food Hydrocoll. 2016, 61, 318-328. [CrossRef]

44. Dombrowski, J.; Gschwendtner, M.; Kulozik, U. Evaluation of structural characteristics determining surface and foaming properties of $\beta$-Lactoglobulin aggregates. Colloids Surf. A 2017, 516, 286-295. [CrossRef]

45. Dombrowski, J.; Gschwendtner, M.; Saalfeld, D.; Kulozik, U. Salt-dependent interaction behavior of $\beta$-Lactoglobulin in relation to its surface and foaming properties. Colloids Surf. A 2018, 558, 455-462. [CrossRef]

46. Qiao, X.; Miller, R.; Schneck, E.; Sun, K. Influence of $\mathrm{pH}$ on the surface and foaming properties of aqueous silk fibroin solutions. Soft Matter 2020, 16, 3695-3704. [CrossRef]

47. Engelhardt, K.; Rumpel, A.; Walter, J.; Dombrowski, J.; Kulozik, U.; Braunschweig, B.; Peukert, W. Protein Adsorption at the Electrified Air-Water Interface: Implications on Foam Stability. Langmuir 2012, 28, 7780-7787. [CrossRef]

48. Richert, M.E.; García Rey, N.; Braunschweig, B. Charge-Controlled Surface Properties of Native and Fluorophore-Labeled Bovine Serum Albumin at the Air-Water Interface. J. Phys. Chem. B 2018, 122, 10377-10383. [CrossRef]

49. Richert, M.E.; Gochev, G.; Braunschweig, B. Specific Ion Effects of Trivalent Cations on the Structure and Charging State of $\beta$-Lactoglobulin Adsorption Layers. Langmuir 2019, 35, 11299-11307. [CrossRef]

50. Schnurbus, M.; Kabat, M.; Jarek, E.; Krzan, M.; Warszynski, P.; Braunschweig, B. Spiropyran Sulfonates for Photo- and pH-Responsive Air-Water Interfaces and Aqueous Foam. Langmuir 2020, 36, 6871-6879. [CrossRef]

51. Honnigfort, C.; Campbell, R.A.; Droste, J.; Ravoo, B.J.; Braunschweig, B. Unexpected monolayer-to-bilayer transition of arylazopyrazole surfactants facilitates superior photo-control of fluid interfaces and colloids. Chem. Sci. 2020, 11, 2085-2092. [CrossRef]

52. Khristov, K. Role of Foam Films in Foam Stability. In Foam Films and Foams: Fundamentals and Applications; Exerowa, D., Gochev, G., Platikanov, D., Liggieri, L., Miller, R., Eds.; CRC Press: Boca Raton, FL, USA, 2018; Chapter 12.

53. Khristov, K.; Exerowa, D.; Minkov, G. Critical capillary pressure for destruction of single foam films and foam: Effect of foam film size. Colloids Surf. A 2002, 210, 159-166. [CrossRef]

54. Dukhin, S.S.; Kovalchuk, V.I.; Aksenenko, E.V.; Miller, R. Surfactant accumulation within the top foam layer due to rupture of external foam films. Adv. Colloid Interface Sci. 2008, 137, 45-56. [CrossRef] [PubMed]

55. Amagliani, L.; Schmitt, C. Globular plant protein aggregates for stabilization of food foams and emulsions. Trends Food Sci. Technol. 2017, 67, 248-259. [CrossRef]

56. Celebioglu, H.Y.; Kmiecik-Palczewska, J.; Lee, S.; Chronakis, I.S. Interfacial shear rheology of $\beta$-lactoglobulin-Bovine submaxillary mucin layers adsorbed at air/water interface. Int. J. Biol. Macromol. 2017, 102, 857-867. [CrossRef] [PubMed]

57. Won, J.; Krägel, J.; Gochev, G.; Ulaganathan, V.; Javadi, A.; Makievski, A.; Miller, R. Bubble-bubble interaction in aqueous $\beta$-Lactoglobulin solutions. Food Hydrocoll. 2014, 34, 15-21. [CrossRef]

58. Ulaganathan, V.; Retzlaff, I.; Won, J.; Gochev, G.; Gehin-Delval, C.; Leser, M.; Noskov, B.A.; Miller, R. $\beta$-Lactoglobulin adsorption layers at the water/air surface: 1 . Adsorption kinetics and surface pressure isotherm: Effect of $\mathrm{pH}$ and ionic strength. Colloids Surf. A 2017, 519, 153-160. [CrossRef]

59. Ulaganathan, V.; Retzlaff, I.; Won, J.; Gochev, G.; Gunes, D.; Gehin-Delval, C.; Leser, M.; Noskov, B.A.; Miller, R. $\beta$-Lactoglobulin adsorption layers at the water/air surface: 2. Dilational rheology: Effect of $\mathrm{pH}$ and ionic strength. Colloids Surf. A 2017, 521, 167-176. [CrossRef]

60. Gochev, G.; Scoppola, E.; Campbell, R.; Noskov, B.A.; Miller, R.; Schneck, E. $\beta$-Lactoglobulin Adsorption Layers at the Water/Air Surface: 3. Neutron Reflectivity Study on the Effect of pH. J. Phys. Chem. B 2019, 123, 10877-10889. [CrossRef]

61. Gochev, G.; Retzlaff, I.; Exerowa, D.; Miller, R. Electrostatic stabilization of foam films from $\beta$-lactoglobulin solutions. Colloid Surf. A 2014, 460, 272-279. [CrossRef] 
62. Ulaganathan, V.; Gochev, G.; Gehin-Delval, C.; Leser, M.; Gunes, D.; Miller, R. Effect of pH and electrolyte concentration on rising air bubbles in $\beta$-lactoglobulin solutions. Colloids Surf. A 2016, 505, 165-170. [CrossRef]

63. Toro-Sierra, J.; Tolkach, A.; Kulozik, U. Fractionation of $\alpha$-lactalbumin and $\beta$-lactoglobulin from whey protein isolate using selective thermal aggregation, an optimized membrane separation procedure and resolubilization techniques at pilot plant scale. Food Bioprocess Technol. 2013, 6, 1032-1043. [CrossRef]

64. Exerowa, D.; Kashchiev, D.; Platikanov, D. Stability and Permeability of Amphiphile Bilayers. Adv. Colloid Interface Sci. 1992, 40, 201-256. [CrossRef]

65. Platikanov, D.; Exerowa, D. Fundamentals of Foam Films. In Foam Films and Foams: Fundamentals and Applications; Exerowa, D., Gochev, G., Platikanov, D., Liggieri, L., Miller, R., Eds.; CRC Press: Boca Raton, FL, USA, 2018; Chapter 3.

66. Garciá Rey, N.; Weißenborn, E.; Schulze-Zachau, F.; Gochev, G.; Braunschweig, B. Quantifying Double-Layer Potentials at Liquid-Gas Interfaces from Vibrational Sum-Frequency Generation. J. Phys. Chem. C 2019, 123, 1279-1286. [CrossRef] [PubMed]

67. Yampolskaya, G.; Platikanov, D. Proteins at fluid interfaces: Adsorption layers and thin liquid films. Adv. Colloid Interface Sci. 2006, 128-130, 159-183. [CrossRef] [PubMed]

68. Clark, D.C.; Coke, M.; Mackie, A.R.; Pinder, A.C.; Wilson, D.R. Molecular diffusion and thickness measurements of protein-stabilized thin liquid films. J. Colloid Interface Sci. 1990, 138, 207-219. [CrossRef]

69. Cascão Pereira, L.G.; Johansson, C.; Radke, C.J.; Blanch, H.W. Surface Forces and Drainage Kinetics of Protein-Stabilized Aqueous Films. Langmuir 2003, 19, 7503-7513. [CrossRef]

70. Blomqvist, B.R.; Ridout, M.J.; Mackie, A.R.; Claesson, P.M.; Wilde, P. Disruption of viscoelastic $\beta$-lactoglobulin surface layers at the air-water interface by nonionic polymeric surfactants. Langmuir 2004, 20, 10150-10158. [CrossRef]

71. Petkova, V.S.; Sultanem, C.; Nedyalkov, M.; Benattar, J.-J.; Leser, M.E.; Schmitt, C. Structure of a Freestanding Film of $\beta$-Lactoglobulin. Langmuir 2003, 19, 6942-6949. [CrossRef]

72. Zawala, J.; Kosior, D.; Malysa, K. Formation and influence of the dynamic adsorption layer on kinetics of the rising bubble collisions with solution/gas and solution/solid interfaces. Adv. Colloid Interface Sci. 2015, 222, 765-778. [CrossRef]

73. Malysa, K.; Cohen, R.; Exerowa, D.; Pomianowski, A. Steady-State Foaming and the Properties of Thin Liquid Films from Aqueous Alcohol Solutions. J. Colloid Interface Sci. 1981, 80, 1-6. [CrossRef]

74. Uhlig, M.; Löhmann, O.; Vargas Ruiz, S.; Varga, I.; von Klitzing, R.; Campbell, R.A. New structural approach to rationalize the foam film stability of oppositely charged polyelectrolyte/surfactant mixtures. Chem. Commun. 2020, 56, 952-955. [CrossRef] [PubMed]

75. Verheul, M.; Pedersen, J.S.; Roefs, S.P.F.M.; de Kruif, K.G. Association behavior of native $\beta$-lactoglobulin. Biopolymers 1999, 49, 11-20. [CrossRef]

76. Taulier, N.; Chalikian, T.V. Characterization of $\mathrm{pH}$-induced transitions of $\beta$-lactoglobulin: Ultrasonic, densimetric, and spectroscopic studies. J. Mol. Biol. 2001, 314, 873-889. [CrossRef]

77. Aymard, P.; Durand, D.; Nicolai, T. The effect of temperature and ionic strength on the dimerisation of ß-lactoglobulin. Int. J. Biol. Macromol. 1996, 19, 213-221. [CrossRef]

78. Sakai, K.; Sakurai, K.; Sakai, M.; Hoshino, M.; Goto, Y. Conformation and stability of thiol-modified bovine $\beta$-lactoglobulin. Prot. Sci. 2000, 9, 1719-1729.

79. Sakurai, K.; Oobatake, M.; Goto, Y. Salt-dependent monomer-dimer equilibrium of bovine $\beta$-lactoglobulin at pH 3. Prot. Sci. 2001, 10, 2325-2335. [CrossRef]

80. Mercadante, D.; Melton, L.D.; Norris, G.E.; Dobson, R.C.J.; Jameson, G.B. Bovine $\beta$-lactoglobulin is dimeric under imitative physiological conditions: Dissociation equilibrium and rate constants over the $\mathrm{pH}$ range of 2.5-7.5. Biophys. J. 2012, 103, 303-312. [CrossRef] [PubMed]

81. Basheva, E.S.; Kralchevsky, P.A.; Danov, K.D.; Stoyanov, S.D.; Blijdenstein, T.B.J.; Pelan, E.G.; Lips, A. Self-Assembled Bilayers from the Protein HFBII Hydrophobin: Nature of the Adhesion Energy. Langmuir 2011, 27, 4481-4488. [CrossRef]

(C) 2020 by the authors. Licensee MDPI, Basel, Switzerland. This article is an open access article distributed under the terms and conditions of the Creative Commons Attribution (CC BY) license (http://creativecommons.org/licenses/by/4.0/). 